\title{
Miogypsinid Foraminiferal Biostratigraphy from the Oligocene to Miocene Sedimentary Rocks in the Tethys Region
}

\author{
Kuniteru Matsumaru \\ Innovation Research Organization, Saitama University, Saitama \\ Japan
}

\section{Introduction}

Tan Sin Hok $(1936,1937)$ has done the anatomical and morphometrical analysis of the family Miogypsinidae at the first time. This is regarded as the important contribution for the Micropaleontology on foraminiferal studies. His studies have developed from the phylogenetic history of the genus Cycloclypeus and their relative species of the family Nummulitidae de Blainville, 1827 (Tan Sin Hok, 1932). The basic materials of these two families have been gathered based on detailed geological fieldworks of many geologists for a long time from the East Indies (Indonesia and its surroundings) as eastern Tethys region or Indo - Pacific region. Therefore the research results of Miogypsinid foraminiferal Biostratigraphy through Tan Sin Hok's morphogenetic method could compare easily with the results of Miogypsinid foraminiferal biostratigraphic research from many areas (Drooger, 1993).

The purpose of this study is to describe the introduction of the Miogypsinid foraminiferal Biostratigraphy and its evolutional lineage based on the author's research and other colleagues results, and research of materials from three areas (Maraş, Palu, and Muş) of Menderes - Taurus Platform, Turkey, respectively.

\section{Method of study}

All microscopical studies were conducted by examination of all sectioned foraminiferal specimens from sample materials collected from the biostratigraphial columnar sections or spot samplings in order to reinforce the space and time distribution of species. Concerning to the observation of outer and inner structure of the foraminiferal test, the microscope used had the lens combination from $\times 20$ to $\times 200$. The biometrical measurement of the equatorial sectioned nucleoconch and peri-nucleoconchal chambers were made by means of a curvimeter and/or scale protractor from a drawing or direct thin section of the nucleoconch and peri-nucleoconchal chambers at magnification of $x 200$. The present study is based on the sectioned specimens and free specimens, which were collected from various localities and/or drill core in Japan, Taiwan, and Turkey.

In the present paper, the morphological terms used are given in the glossary and the important criteria for detailed measurements (Figure 1). The measurements were taken from the equatorial and axial (= vertical) sections of megalospheric specimens which exhibited 
considerable variations in measurements. Also those of microspheric specimens are used supplementary for the measurements and for observation of structure. Since all characters are not measurable, the statistical analysis and consideration from measurements are not perfectly alternative to traditional description, but merely supplementary to it, but provides a more objective basis for comparison between the measurable characters of important morphology and/or structure. The measured parameters are explained for the following terminology as defined by many authors (Figure 1).

On nucleoconch (= embryonic chambers), as showing the development of embryonic chambers is explained as below.

DI: diameter of protoconch, the first chamber of embryonic chambers, consisting protoconch and deuteroconch (Figure 1a). Generally inner protoconch is measured at right angle for the center line of both protoconch and deuteroconch. DI is Drooger's (1952) symbol or definition. The next two is also his symbol and definition.

DII: diameter of duteroconch, the second chamber of embryonic chambers (Figure 1a).

DII/DI: ratio of diameter between protoconch and deuteroconch.

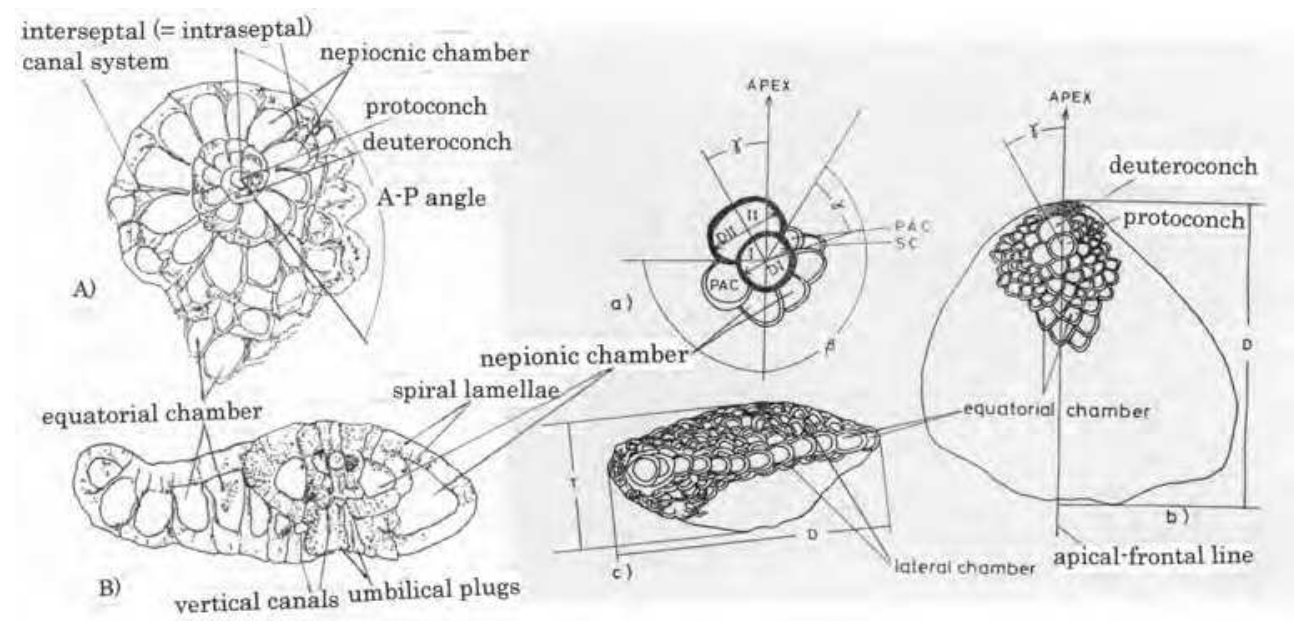

Fig. 1. Terminology of the Miogypsinid foraminifera. A. Equatorial section of Miogypsinella boninensis Matsumaru, and B. Axial (= Vertical) section of Miogypsinella boninensis Matsumaru. a. Enlargement of the apical portion of equatorial section of Miogypsina globulina (Michelotti). b. Equatorial section of Miogypsina globulina (Micgelotti). c. Axial (=Vertical) section of Miogypsina globulina (Michelotti). I = protoconch. II = deuteroconch. $\mathrm{PAC}=$ principal auxiliary chamber. $\mathrm{SC}=$ symmetrical $(=$ closing $)$ nepionic chamber. $\mathrm{DI}=$ diameter of protoconch. DII = diameter of deuteroconch. $\alpha=$ angle between a line joining the center of the protoconch and the junction of both walls of the protoconch and deuteroconch, and another line connecting the said center and a mid-point of the posterior wall of the symmetrical chamber. $\beta=$ angle representing the whole development area of both nepionic spirals of the protoconch surround with both spirals starting from both PAC. $\mathrm{V}=200 \mathrm{a} / \mathrm{B}=$ indicate from the absence of the second PAC representing by the value 0 to the protoconchal spirals of equal length by the value 100. $\gamma=$ angle between the apical frontal line and line joining the center of the protoconch and deuteroconch. 
On nepionic chambers, as base character of the principle of nepionic acceleration (including nepionic retardation, but with additional development of new nepionic spirals) by Tan Sin Hok's $(1936,1937)$ theory is explained as below.

Parameter X: number of spiral nepionic chambers developed in peri-nucleoconch (= periembryonic chambers). This is Tan Sin Hok's (1936) “Rotalia-Anfang und mit intraseptalen Spalten". Drooger (1952) counts and used as one of important characters as symbol or definition, parameter $X$. The value $X$ is progressed until the new nepionic spirals of parameter a as stated below. In the genus Miogypsinella with trochoid spirals (Figure 2, top left) and genus Miogypsinoides with planispiral (Figure 2, top right), the nepionic chambers are counted in number as parameter $\mathrm{X}$ in a spiral arrangement. This is continued until the presence of Miogypsina primitiva (Tan Sin Hok) (Figure 2, second left from top), which is considered to be the genus Miogypsinopsis Hanzawa, 1940, and Miogypsina borneensis Tan Sin Hok, 1936. The number of parameter $\mathrm{X}$ is getting decrease from Miogypsinella boninensis Matsumaru, 1996 (Figure 1A, $\mathrm{X}=25$ ) to Miogypsina primitiva (Figure 2, $\mathrm{X}=10$ ) and Miogypsina borneensis (Plate 2, figures $1-3, X=6)$, and it is regarded as nepionic retardation. The next step is beginning at the development of secondary nepionic spirals from the second prinicipal auxiliary chamber and situated in the opposite side of the primary principal auxiliary chamber (Figure 1a; parameter a). Therefore this evolutionary lineage is generally regarded as Tan Sin Hok's $(1936,1937)$ nepionic acceleration from the genus Miogypsinella to genus Miogypsina. The following four parameters are based on Drooger $(1952,1963)$.

Parameter a: small nepionic spiral developed from the second principal auxiliary chambers (Figure 1a). This is the secondary or short nepionic spirals, situated under the outer wall of protoconch. This spiral is arc length and measured by the angle between the line connecting the center of protoconch and rough inscribed line touchrd between deuteroconch and second principal auxiliary chamber, and the line connecting the center of protoconch and center line of closing chamber, which is situated between large and small nepionic spirals developed from opposite direction of two principal auxiliary chambers (Figure 1a). Parameter a in Figure $1 \mathrm{a}=40^{\circ}$.

Parameter $\mathrm{B}$ : total nepionic spirals including a closing chamber (= symmetrical chamber, Figure 1a, sc) under the outer wall of protoconch, developed from two primary and secondary principal auxiliary chambers. This spiral is also arc length and measured by the angle between two rough inscribed lines from both two principal auxiliary chambers and deuteroconch, connecting with the center of protoconch (Figure 1a). Parameter $B$ in Figure $1 \mathrm{a}=240^{\circ}$. Generally the primary or long nepionic spirals from the primary principal auxiliary chamber is larger arc than the secondary or short nepionic spirals.

Parameter V (= $200 \mathrm{a} / \mathrm{B})$ : ratio of small or short nepionic spirals $(\mathrm{a})$ for total short and long nepionic spirals (ß), and parameter a will be stopped at the midpoint of parameter $B$. Then the ratio times 200 are expressed as a continuous scale with units from 0 to 100 . When a closing or symmetry chamber is situated at the midpoint of both protoconchal nepionic spirals, $\mathrm{V}$ value is indicated as 100. When a short nepionic spiral or a closing chamber isn't present, $\mathrm{V}$ value is indicated as 0 . Parameter V in Figure $1 \mathrm{a}=40^{\circ} / 240^{\circ} \times 200=33.332$. When measuring these parameters in numerous specimens in a sample, there is sometimes exceed over 100 in V value, but it is few case.

Parameter $\gamma$ : angle between the apical-frontal line of test through the center of protoconch and the line connecting centers of embryonic chambers (Figure 1b). If the primary principal auxiliary chamber is situated below the line connecting of centers of embryonic chambers, parameter $\gamma$ is positive, and reverse is negative (Plate 2, figure 2). Parameter $\gamma$ in Figure 1a = positive $30^{\circ}$. 


\section{Genus Miogypsinella Hanzawa, 1940}
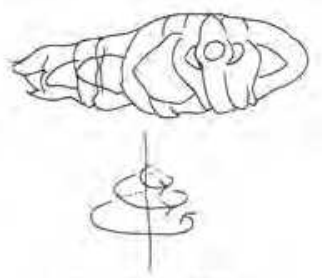

trochoid spirals
Genus Miogypsinoides Yabe and Hanzawa, 1928
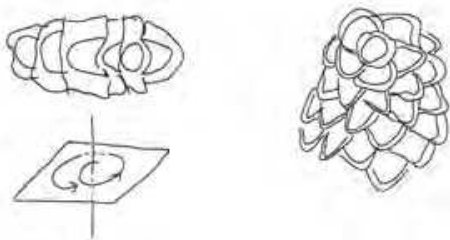

planispiral

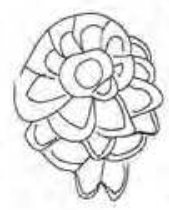

Miogypsins primitiva (Tan Sin Hok, 1936),

included in Genus Miogypsinopsis Hanzawa,

1940, and is regarded as the genus Miogypsing
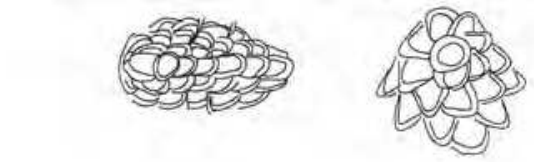

Genus Miogypsina Sacco, 1893
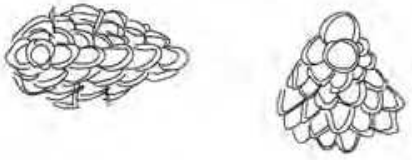

Tania inokoshiensis Matsumaru, 1990

type species of Genus Tania Matsumaru, 1990.

Genus Miolepidocyclina A. Silvestri, 1907
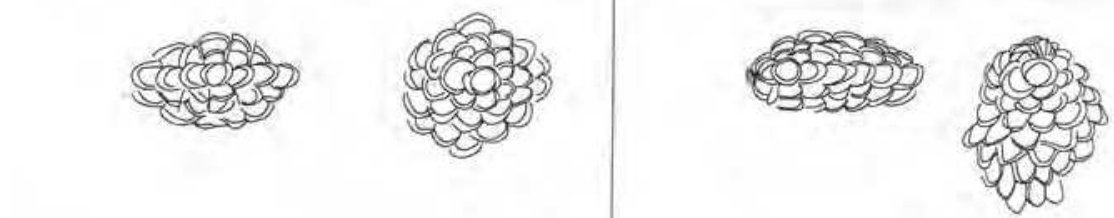

Genus Lepidosemicyclina Rutten, 1911
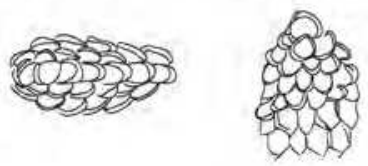

Miogypsina mexicana Nuttall, 1933, type species of Genus Miogypsinita Drooger, 1952, and is regarded as intermediate form between the Miogypsina and Miolepidocyclina
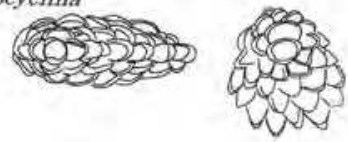

Fig. 2. Sketch of several genera and species of the family Miogypsinidae Vaughan, 1928 in the Tethys region. Two nepionic spirals are shown as trochoid spirals and planispirals. 
Parameter A-P angle: arc length of nepionic spirals starting from embryonic chambers, and ending to the apical point of test (Hanzawa, 1957, p. 91; table 6), and A-P angle in Figure 1A , $\mathrm{AP}=360^{\circ}+145^{\circ}=505^{\circ}$.

Designation of the species: In the previous investigation by many authors, the species units of miogypsinid foraminifera have mainly been established by applying from the mean $X$ value to mean $\mathrm{V}$ value (mean $\mathrm{X}$ - mean $\mathrm{V}$ value scale), in addition to traditional main observation, i.e. presence and/or absence of lateral chambers, shape and arrangement of equatorial chambers, arrangement of stolons and canal system in chamber walls, and development of pillars and/or sometimes spines. Species of Figure 1A, B is Miogypsinella boninensis Matsumaru, carrying Parameter $X(X=25)$ and A-P angle $\left(\mathrm{AP}=505^{\circ}\right)$, and that of Figure 1 a-c is Miogypsina globulina (Michelotti), carrying Parameter V $(\mathrm{V}=33.3)$ and Parameter $\gamma\left(\gamma=+30^{\circ}\right)$. Parameter X exists until 5, and doesn't exist 4 .

\section{Stratigraphy, faunal succession, and correlation}

In this chapter, the author describes the introduction of the fundamental Miogypsinid foraminiferal Biostratigraphy, faunal succession and phylogenetic lineage, and correlation.

1. Ogasawara Islands, Japan

The basal Oligocene carbonate sedimentary rocks in Japan has been known in Chichi-Jima (island) and Minami-Jima, Ogasawara Islands, Japan (Matsumaru, 1996) (Figures 4-7). In there, six stratigraphic sections in the Minamizaki cape, SW of Chichi-Jima, and two stratigraphic sections and several spot samplings in the Minami-Jima, Ogasawara Islands were examined for the larger foraminiferal biostratigraphy of the Minamizaki Limestone (Formation) with maximum $244 \mathrm{~m}$ thick, overlying the basement volcanic rocks (boninite, andesite, dacite, and others) (Figures 5-6). Two larger foraminiferal assemblages (Assemblage IV and Assemblage V) during Oligocene age were recognized in the respective sections of biostratigraphic sequence, based on the stratigraphic range of larger and smaller foraminifera in association with planktonic foraminifera. The Assemblage IV is the Eulepidina dilatata (Michelotti) - E. ephippioides (Jones and Chapman) - Heterostegina borneensis van der Vlerk Assemblage and the Assemblage $\mathrm{V}$ is the Miogypsinella boninensis Spiroclypeus margaritatus (Schlumberger) - Austrotrillina howchini (Schlumberger) Assemblage. Both assemblages were correlative with Tertiary $\mathrm{c}$ and/or Tertiary $\mathrm{d}$, and Tertiary e1-2 to Tertiary e4 of the East Indies Letter Stages (Leupold and van dr Vlerk, 1931), respectively, and were also correlative with Zone P 18?-21 or Globigerina sellii (Borsetti) Zone - Globorotalia opima opima Bolli Zone, and Zone P 21? or P 22 of planktonic foraminiferal zonations. The Assemblage IV is correlated with the fauna of the Tertiary beds of 1629 to 2687 feet, in Eniwetok Atoll Drill Holes (Cole, 1957), and 1723.5 to 2359.5 feet, in Bikini Atoll Drill Holes (Cole, 1954), respectively, because of the coexistence and range of Eulepidina ephippioides (Jones and Chapman), Heterostegina borneensis van der Vlerk, H. duplicamera Cole, and Halkyardia minima (Liebus) (Figure 4). The Assemblage V is also correlated with Tertiary e limestones in bore-holes at Eniwetok Atoll Drill Holes at depth from 1210 to 1599 feet, and at Bikini Atoll Drill Holes at depth from 1597.5 to 1671 feet, respectively, where Miogypsinella grandipustula (Cole) and Miogypsinella ubaghsi (Tan Sin Hok) were reported by Cole $(1954,1957)$ (Figure 4).

Two assemblages (IV and V), Ogasawara Islands are referable in the geological age to Early to late Early Oligocene, and early Late Oligocene, respectively (Figures 6-7). According to Kaneoka et al. (1970) and Tsunakawa (1983), K-Ar radiometric ages on boninite, andesite, 
dacite and quartz dacite of basal volcanic rocks of Chichi-Jima, Ogasawara Islands is regarded as 43.0 to $29.4 \mathrm{Ma}$, and the most young age of volcanics is $26.7 \mathrm{Ma}$. The Minamizaki Limestone is regarded as submerged karst topography, with summits sticking up from the sea as peninsulas of Minamizaki Cape, Chichi-Jima and Minami-Jima (island) and a lot of islets. The largely submerged Minamizaki Limestone is estimated to be more than $244 \mathrm{~m}$ thick and overlies the basement volcanic rocks of lavas and pyroclastics of boninite and other rocks as stated above.

The Assemblage IV is at least regarded as Tertiary d, in this study, due to occurrence of Heterostegina borneensis van der Vlerk, H. duplicamera Cole, Eulepidina dilatata (Michelotti), E. ephippioides (Jones and Chapman), Pararotalia mecatepecensis (Nuttall), Paleomiogypsina boninensis Matsumaru, Borelis pygmaeus (Hanzawa) and Nephrolepidina marginata (Michelotti), with associated planktonic foraminifera of Zone P 21(Blow, 1969) such as Globorotalia opima nana Bolli, G. cf. opima opima Bolli, and G. gr. opima Bolli. They are correlated with the Late Eocene to Neogene time scale (official website of ICS, 2004; Berggren et al., 1995) (Figures 6-7, 9). The Assemblage V is assigned to Tertiary e1-2 to Tertiary e3, in this study, due to occurrence of Miogypsinella boninensis Matsumaru, Spiroclypeus margaritatus (Schlumberger), Cycloclypeus eidae Tan Sin Hok, which is junior synonym of C. koolhoveni Tan Sin Hok and/or C. oppenoorthi Tan Sin Hok, Paleomiogypsina boninensis, Boninella boninensis Matsumaru, Flosculinella reicheli Mohler, which is a synonym of Flosculinella globulosa Rutten, and Austrotrillina howchini (Schlumberger). This fauna didn't associate with diagnostic planktonic foraminifera, but it should be assumed to be Zone P 22 from the biostratigraphical occurrence (Figure 6). Although the basal part of the Minamizaki Limestone is obscure due to subsidence under the sea, Pararotalia mecatepecensis may evolve into Paleomiogypsina boninensis due to nepionic acceleration and well-developed subsidiary chambers during early Oligocene (Rupelian) and/or latest Eocene (Priabonian?) due to basal volcanic radiometric age (Figures 3-4, 7). Also Paleomiogypsina boninensis evolved into Miogypsinella boninensis due to biostratigraphical occurrence, Tan Sin Hok's nepionic acceleration, and development of equatorial chambers (Figures 3-4, 7). Miogypsinella boninensis has the character of number of nepionic chambers (mean $\mathrm{X}=27$ ) and A-P angle (mean $\left.\mathrm{AP}=578^{\circ}\right)$ (Figure 4).

2. Komahashi-Daini Seamount, Japan

The larger foraminiferal assemblage has been discovered from limestone blocks dredged at two sites on the Komahashi-Daini Seamount of the Kyushu-Palau Ridge, Japan (sample

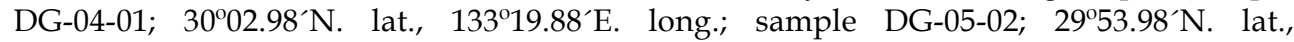
$133^{\circ} 22.66^{\prime}$ E. long.; Mohiuddin et al., 2000) (Figure 5). The assemblage is dominated by the occurrence of Miogypsinella ubaghsi (Tan Sin Hok), Spiroclypeus margaritatus, Heterostegina borneensis, Eulepidina dilatata, E. ephippioides, Nephrolepudina marginata, and Austrotrillina howchini, and was correlated with the top part of the Minamizaki Limestone of Ogasawara Islands. In this study, the Komahashi-Daini larger foraminiferal fauna may be regarded as the fauna from the covering limestone of the Minamizaki Limestone, Ogasawara Islands, because Miogypsinella ubaghsi didn't occur from the top member of the Minamizaki Limestone (Figures 4, 6-7). Miogypsinella ubaghsi has the character such as number of nepionic chambers $(X=21)$ and A-P angle $\left(A P=395^{\circ}\right)$ (Mouhiddin et al, 2000, fig.8-3). Judging from the stratigraphic correlation and nepionic acceleration, Miogypsinella boninensis evolved into Miogypsinella ubaghsi as the author's consideration (Matsumaru, 1996, p. 39, fig. 24) (Figure 4). 

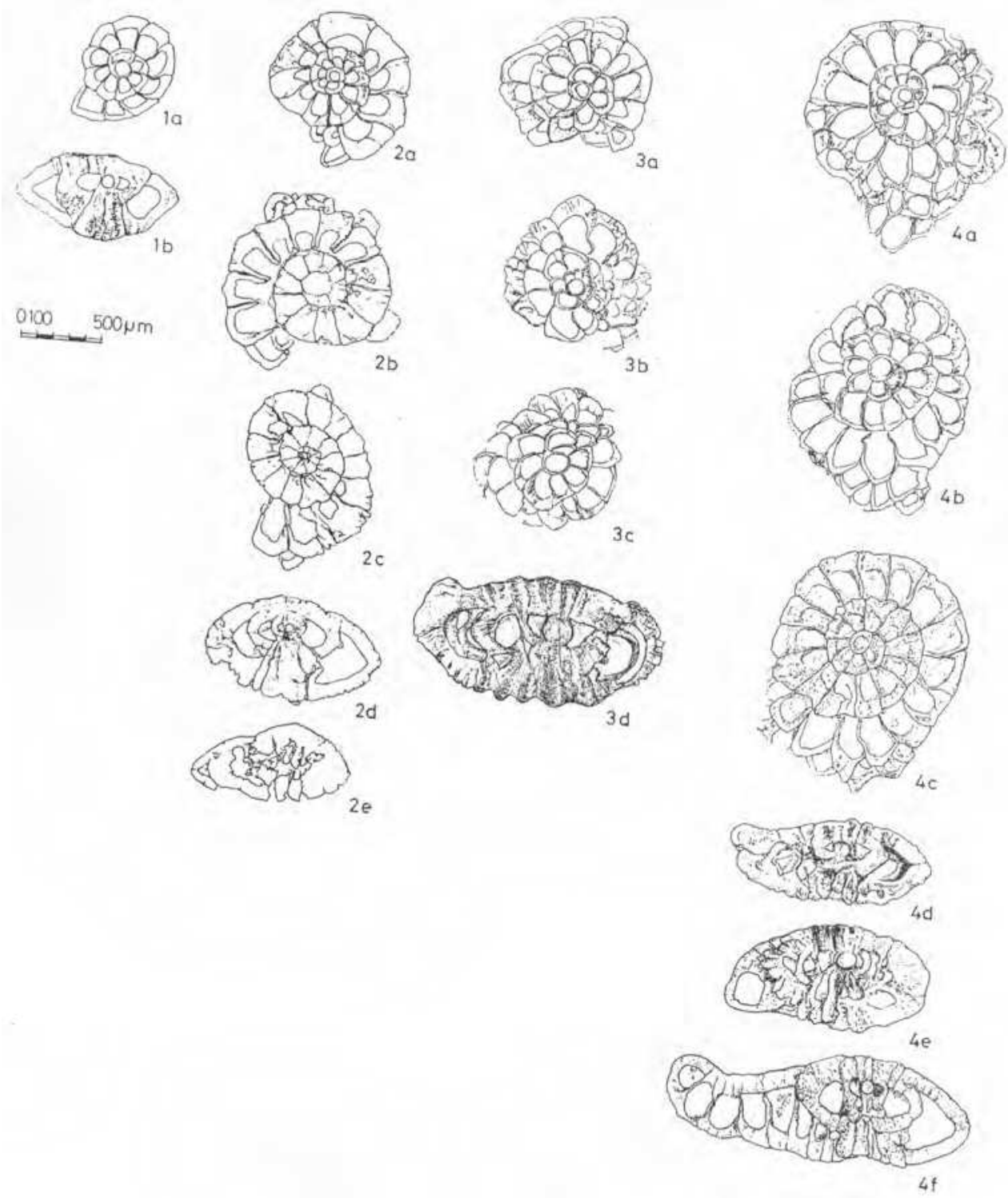

Fig. 3. Drawings of the embryonic, nepionic, and neanic stages in the equatorial and axial sections of species of: 1. Pararotalia mecatepecensis (Nuttall), 2. Paleomiogypsina boninensis Matsumaru, 3. Boninella boninensis Matsumaru, 4. Miogypsinella boninensis Matsumaru (Matsumaru, 1996, fig. 23). 


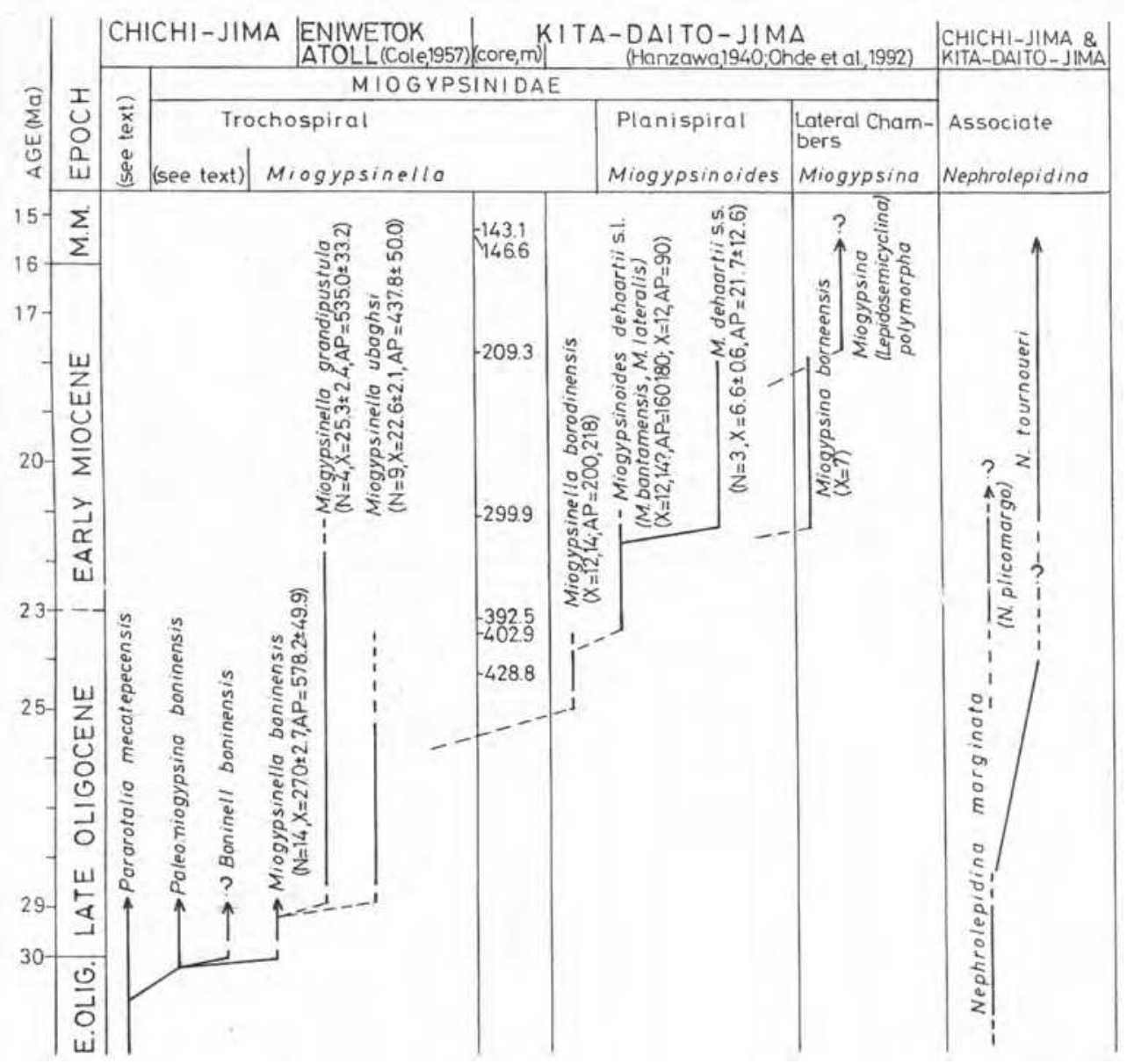

Fig. 4. Evolution of the western Pacific Miogypsinids from Chichi-Jima, Eniwetok Atoll, and Kita-Daito-Jima, and the stratigraphic position of associated Nephrolepidina species from Chichi-Jima and Kita-Daito-Jima (Matsumaru, 1996, fig. 24). 


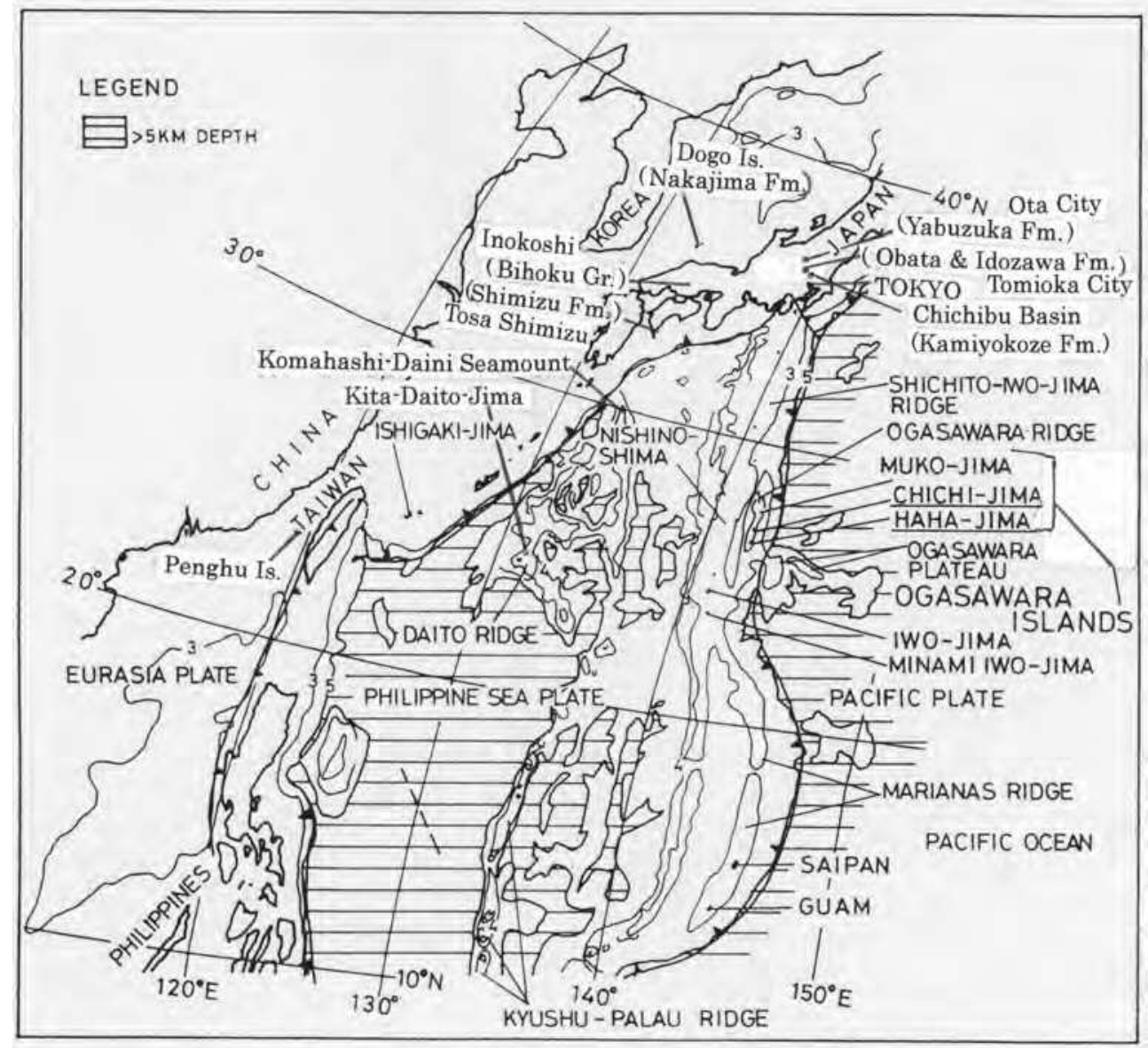

Fig. 5. Geographical locations from Japan and Taiwan treated in this study (Retouch to Matsumaru, 1996, fig. 1). 


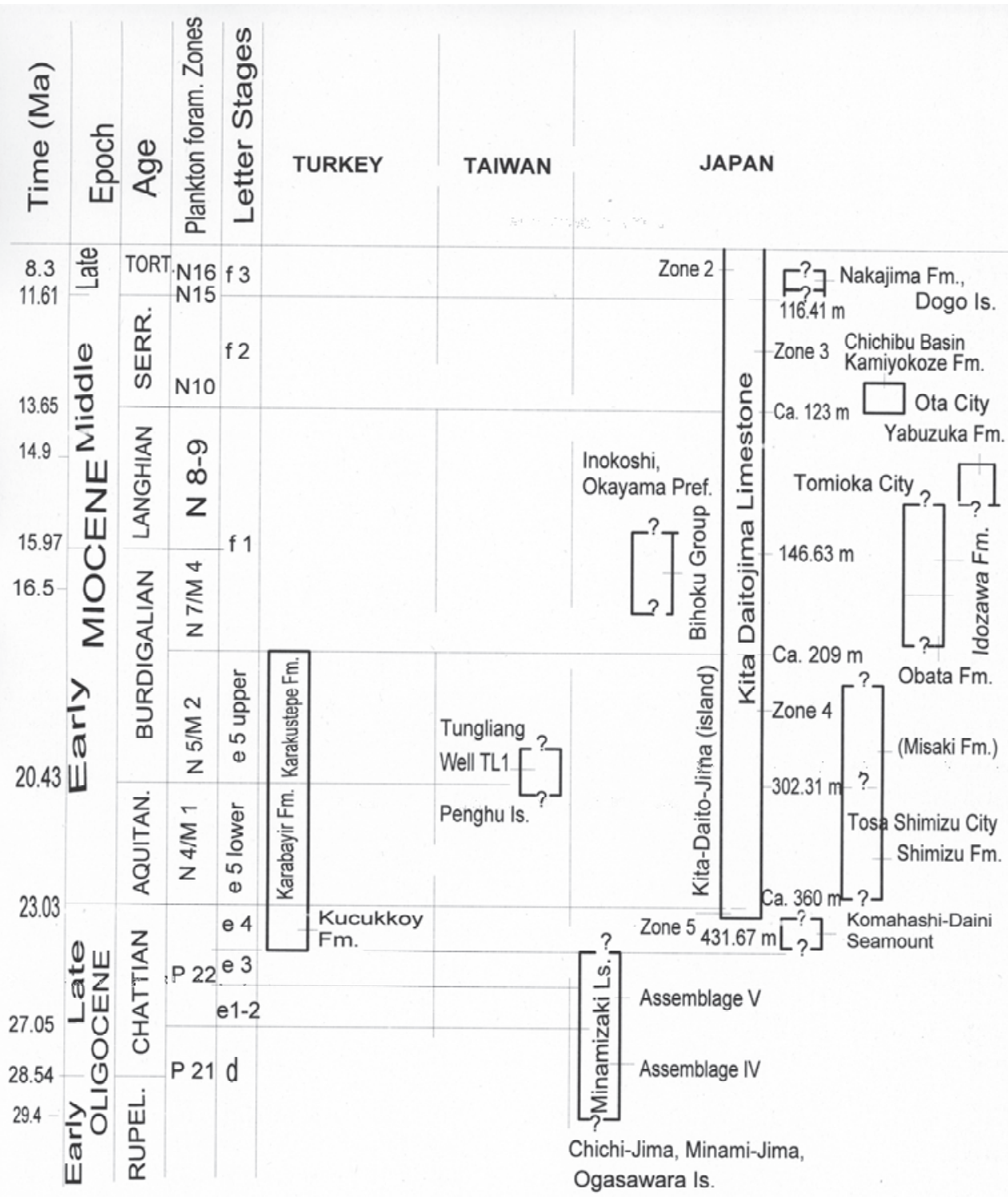

Fig. 6. Correlation chart between the stratigraphic columnar sections treated in Turkey (Matsumaru et al., 2010); Taiwan (Matsumaru, 1968); and Japan (Hanzawa, 1940; Matsumaru, 1967, 1971, 1972, 1977, 1980, 1982, 1996; Matsumaru et al., 1993; Mohiuddin et al., 2000; Nomura et al., 2003). 


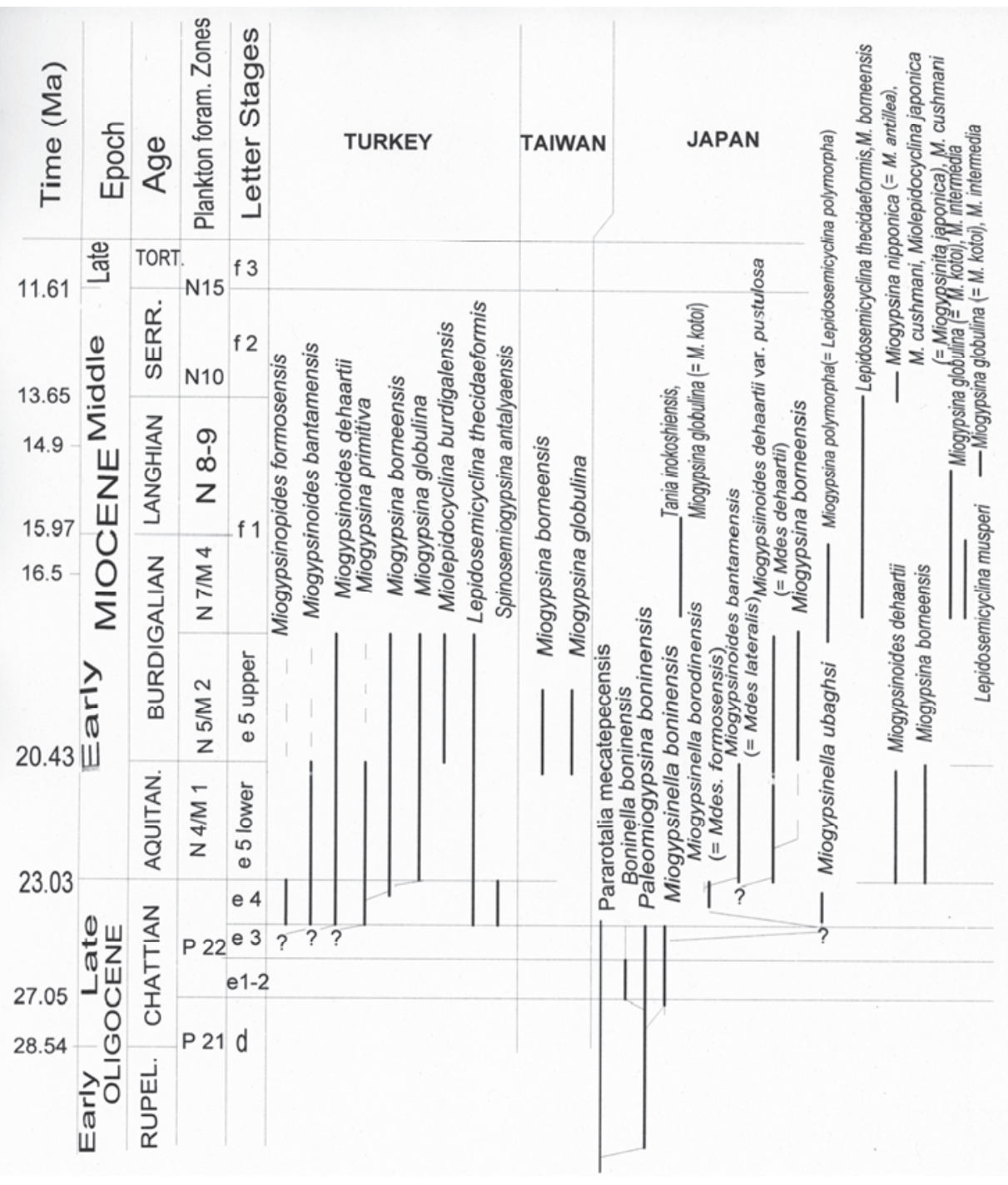

Fig. 7. Biostratigraphic occurrence of Miogypsinid foraminifera from Turkey, Taiwan and Japan. 
3. Kita-Daito-Jima, Okinawa Prefecture, Japan

Five foraminiferal fauna have been established into depth zones of the drill cores (431.67$2.68 \mathrm{~m}$ thick) of the Kita Daitojima Limestone, at Kita-Daito-Jima (North Borodino Island, $25^{\circ} 56^{\prime} 47^{\prime \prime}$ N. lat., 131 $17^{\prime} 30^{\prime \prime E}$. long.), Okinawa Prefecture, Japan (Hanzawa, 1940) (Figures 47). Hanzawa's Zone 5 (431.67-394.98 m) is characterized by the occurrence of Miogypsinella borodinensis Hanzawa, which is later assigned to Miogypsinoides borodinensis (Hanzawa) without lateral chambers or with incipient lateral chambers by Hanzawa (1964). This species evolved from Miogypsinoides formosensis Yabe and Hanzawa (Hanzawa, 1964, p. 309, 311) due to decrease of number of nepionic chambers. In this study, Miogypsinella borodinensis of probable holotype specimen has the character of both number of nepionic chambers $(X=13)$ and A-P angle $\left(\mathrm{AP}=220^{\circ}\right.$ ) (Hanzawa, 1940, pl. 39, fig.6), and Miogypsinoides formosensis of probable holotype specimen has the character of both number of nepionic chambers $(X=16)$ and A-P angle $\left(\mathrm{AP}=240^{\circ}\right.$ ) (Yabe and Hanzawa, 1928, fig. 1a). Hanzawa's consideration is right, but there is unknown on species variation of both species. Both forms could fortunately be found from the Küçükkoy Formation in Korkuteli area, Bey Dağlari Autochton, Menderes-Taurus Platform, SW Turkey (Matsumartu et sl., 2010) (Figures 6-9). The author in Matsumaru et al. (2010) described Miogypsinoides formosensis (Yabe and Hanzawa) and regarded their all specimens of schizont (A1 form) and gamont (A2 form) of sexual reproduction, rather planispiral, and carrying rudimentary lateral chambers (Matsumaru et al., 2010, pl. 2, fig. 1) from the Küçükkoy Formation. A specimen (Matsumaru et al., 2010, pl. 1, fig. 8) has the character of number of nepionic chambers (X= 13) and A-P angle $\left(\mathrm{AP}=210^{\circ}\right)$, while a specimen (Matsumaru et al., 2010, pl. 1, fig. 9) has the character of number of nepionic chambers $(X=16)$ and A-P angle $\left(\mathrm{AP}=250^{\circ}\right)$. Another specimen (Matsumaru et al., 2010, pl. 1, fig. 10) has the character of number of nepionic chambers $(X=13)$ and A-P angle $\left(\mathrm{AP}=260^{\circ}\right)$. As such the Küçükkyoy Formation carrying Miogypsinoides formosensis was correlated with the Zone 5 drill cores (431.67-ca. $360 \mathrm{~m}$, as stated below) of the Kita Daitojima Limestone due to occurrence of Miogypsinella borodinensis (= Miogypsinoides formosensis) (Matsumaru et al., 2010).

Sr isotope age of Hanzawa's Zone 5 is regarded as 24.3 to $23.5 \mathrm{Ma}$ (Ohde and Elderfield, 1992), and then Hanzawa's Zone 5 is applied for drill cores from 431.67 to ca. $360 \mathrm{~m}$ from their age assignment (Figures 6-7). Judging from the Tan Sin Hok's nepionic acceleration, Miogypsinella ubaghsi occurred from the limestone of Komahashi-Daini Seamount evolved into Miogypsinella borodinensis (= Miogypsinopides formosensis) occurred from Zone 5 drill cores of Kita Daitojima Limestone due to reduction of number of nepionic chambers and low value of A-P angle (Figure 7).

4. Tosa-Shimizu City, Shikoku, Japan

The Shimizu Formation, Ashizuri Cape, Tosa Shimizu City, Shikoku, Japan occupies the southernmost part of the Shimanto Belt, one of Japanese Tectonic Zones, and consists of calcareous sandstone and volcanic conglomerate into the coherent rock facies and chaotic rock facies (Figures 5-7). The calcareous sandstone of the Shimizu Formation occurred Miogypsinoides dehaartii (van der Vlerk) (Plate 2, figure 12), Miogypsina sp, which is assigned to M. borneensis, Nephrolepidina praejaponica Matsumaru, Spiroclypeus margaritatus (Schlumberger) and Victoriella conoidea (Rutten) in the location of Ashizuri Cape, Tosa

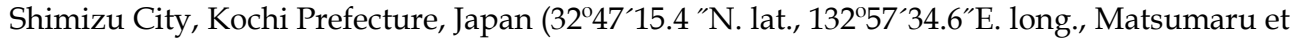
al., 1993). The Misaki Formation of Tosa Shimizu City is composed on alternation of sandstone and mudstone, and crops out in $4 \mathrm{~km} \mathrm{NW}$ of Ashizuri Cape and there is no 
contact with the Shimizu Formation. The lower member of the Misaki Formation occurs Nephrolepidina praejaponica Matsumaru, Amphistegina radiata (Fichtel and Moll), Sphaerogypsina globulus (Reuss) and Rotalia spp. and also occurrs planktonic foraminifera such as Catapsydrax stainforthi Bolli, Globigerina altiapertura Bolli, G. immaturus Leroy, G. subquadratus Brönnimann, Globorotalia zealandica Hornibrook, Globorotaloides suteri Bolli and Praeorbulina sicana (de Stefani) (Matsumaru and Kimura, 1989). At least Nephrolepidina praejaponica-bearing Misaki Formation is assumed to be correlated with Zone N5 to lower Zone N7 of planktonic foraminiferal Zonations (Blow, 1969). Therefore the Miogypsinoides dehaartii and Miogypsina borneensis bearing Shimizu Formation is underlain the Misaki Formation, and its age is regarded as Zone N4 or Zone N 5? (Blow, 1969) (Figures 6-7). Both embryonic and nepionic stages of Miogypsinoides dehaartii and Miogypsina borneensis from the Shimizu Formation are insufficient in oblique and vertical sections. The Shimizu Formation carrying Miogypsinoides dehaartii and Miogypsina borneensis may mostly be correlated with the upper Zone 4 drill cores (302.31 to ca, 209 m thick) of the Kita Daitojima Limestone due to the upper occurrence of Miogypsinoides dehaartii var. pustulosa (= M. dehaartii, s. 1.) and Miogypsina borneensis, and without Miogypsinoides bantamensis (Hanzawa, 1940) (Figures 4-7). Miogypsinoides dehaartii s. 1. of the Kita Daitojima Limestone has the character of number of nepionic chambers $(X=7,7$ and 7$)$ and A-P angle $\left(\mathrm{AP}=20^{\circ}, 10^{\circ}\right.$ and $\left.20^{\circ}\right)$ in three specimens (Hanzawa, 1940, pl. 40, figs. 29, 27 and 26 ), and Miogypsina borneensis of the Kita Daitojima Limestone has the character of number of nepionic chambers $(X=7$ and 7$)$ and A-P angle $\left(\mathrm{AP}=10^{\circ}\right.$ and $\left.30^{\circ}\right)$ in two specimens (Hanzawa, 1940, pl. 41, figs. 19-20). However Miogypsinoides bantamensis (Tan Sin Hok) in the lower Zone 4 drill cores (ca. 360 to $302.31 \mathrm{~m}$ thick) has the character of number of nepionic chambers $(X=12,12$ and 13) in three specimens and A-P angle ( $\mathrm{AP}=165^{\circ}, 180^{\circ}$ and $195^{\circ}$ ) (Hanzawa, 1040, pl. 39, figs. 16-17, 19). Then Miogypsinoides bantamensis evolved into Miogypsinoides dehaartii s. 1 . due to biostratigraphic occurrence and Tan Sin Hok's nepionic acceleration, with reduction of number of nepionic chambers as explained above (Figure 7). Moreover Miogypsinoides dehaartii without lateral chambers evolved into Miogypsina borneensis with lateral chambers (Figure 7).

5. Tungliang Well TL1, Paisa Island, Penghu Islands, Taiwan

Miogypsina globulina (B form, but not microspheric form; Matsumaru, 1968, pl. 36, figs. 1-6) with nepionic chambers arranged single type (= Miogypsina borneensis Tan Sin Hok) and Miogypsina globulina (A form; Matsumaru, 1968, pl. 35, figs. 1-6) with two unequal protoconchal nepionic spirals (= Miogypsina globulina (Michelotti)) have been found in Miogypsina bearing calcareous sandstone at about $500 \mathrm{~m}$ depth in the Tungliang Well TL1, located at about $800 \mathrm{~m}$ NE of Tungliang Village, Paisa Island, Penghu Islands, Taiwan (Figure 5). Miogypsina borneensis has the character of number of nepionic chambers $(X=6,5$, $6,6,7$, and 6 ; mean $\mathrm{X}=6)$ in 6 specimens $(\mathrm{n}=6)$ and A-P angle $\left(\mathrm{AP}=10^{\circ}, 15^{\circ}, 6^{\circ}, 6^{\circ}, 15^{\circ}\right.$ and $25^{\circ}$ ) (Matsumaru, 1968, pl. 36, figs. 1-6). Miogypsina globulina has the characters of ratio of two nepionic spirals $(\mathrm{V}=32.56,18.18,15.20$ and 28.36; mean $\mathrm{V}=23.58)$ in 4 specimens $(\mathrm{n}=$ 4) (Matsumaru, 1968, pl. 35, figs. 1-4). Therefore the Miogypsina bearing sandstone of Well TL1, carrying Miogypsina borneensis and M. globulina, but not Miogypsinoides dehaartii, is stratigraphically younger than the Shimizu Formation and upper Zone 4 of the Kita Daitojima Limestone, which carry Miogypsinoides dehaartii and Miogypsina borneensis (Figures 6-7). As such Miogypsina borneensis carrying number of nepionic chambers (mean X=6) from the Miogypsina sandstone, Well TL1, Paisa Island, Penghu Islands is necessarily fewer 
number of nepionic chambers than $M$. borneensis carrying number of nepionic chambers (mean $X=7$ ) from the upper Zone 4 drill cores of Kita Daitojima Limestone, Kita-Daito-Jima. 6. Early to Middle Miocene Miogypsina from Honshu, Japan

The Obata and Idozawa Formations, Tomioka Group, Honshu, Central Japan are known as representative sedimentary rocks of late Early to early Middle Miocene age in Japan (Matsumaru, 1967, 1977) (Figures 5-7). Japanese Miogypsina has been known to occur from the Lower/Middle Miocene sedimentary rocks in Honshu, Japan as Miogypsina kotoi Hanzawa, 1931, Miolepidocyclina (= Miogypsinita) japonica Matsumaru, 1972, Miogypsina japonica Ujiie, 1973 (= M. globulina (Michelotti)), M. nipponica Matsumaru, 1980 (= M. antillea (Cushman) and M. cushmani Vaughan steps of nepionic acceleration), and Tania inokoshiensis Matsumaru, 1990, in addition to Miogypsina borneensis Tan Sin Hok, Lepidosemicyclina thecidaeformis (Rutten), and Lepidosemicyclina musperi (Tan Sin Hok) (Plates 1-2). According to Matsumaru and Takahashi (2004), Japanese Miogypsina is discussed as the followings: The measurement data of topotype specimen of Miogypsina kotoi Hanzawa is as follows: $\mathrm{V}=20$, $\mathrm{DI}=120 \times 70$ micron, DII/DI $=1.0$, and $\gamma=35^{\circ}$, and Miogypsina kotoi Hanzawa is junior synonym of Miogypsina globulina (Michelotti). Miogypsina japonica Ujiie from type locality and other three stations has the following data: $\mathrm{V}=40.9$ and DII/DI $=1.34, \mathrm{~V}=39.2$ and $\mathrm{DII} / \mathrm{DI}=1.28, \mathrm{~V}=36.1$ and DII/DI $=1.32$, and $\mathrm{V}=47.2$ and DII/DI $=1.24$. Then Miogypsina japonica Ujiie doesn't represent Miogypsina cushmani Vaughan, 1924 of V scale of Drooger (1963), but represent $M$. globulina due to having of $V$ value (mean $V=40.85)(n=4)$. The Miogypsina population at Nogami locality found from the Obata Formation, Tomioka Group, Tomioka City, Gunma Prefecture is known as V value (mean V = 43.93 in 20 specimens), which is assigned to Miogypsina globulina (Matsumaru, 1967, 1977) (Figures 5-6). However, critical viewing Miogypsinid population, Lepidosemicyclina musperi (Rutten) and Miogypsina cushmani Vaughan with V value $(\mathrm{V}=77)$ can be found from the Obata Formation (Figure 7). The Obata Formation is conformably overlain by the basal tuff (T6 Tuff or Wagoubashi Tuff, Matsumaru, 1967) of the Idozawa Formation carrying Miogypsina globulina, and the fission truck age of the T6 Tuff is 16. $5 \pm 1.9$ Ma by Nomura and Ohira (1998). The Idozawa Formation is conformably overlain by the basal tuff (T5 Tuff, Matsumaru, 1967) of the Haratajino Formation, which yields Orbulina suturalis Brönnimann, O. universa d'Orbigny, Globorotalia birnagea Blow, Globigerinoides sicanus de Stefani and others (Matsumaru, 1977). The fision truck age of T5 Tuff is $15.2 \pm 0.5$ Ma (Nomura and Ohira, 2002). Then the geological age of the Idozawa Formation is roughly Langhian of early Middle Miocene based on Zone N8 (Blow, 1969; Berggren et al., 1995), and the age of T5 Tuff is regarded to be the age of the Orbulina datum-plane. The Miogypsina population at Kanayama locality found from the Yabuzuka Formation at Ota City, Gunma Prefecture is known as $\mathrm{V}$ value (mean $\mathrm{V}=47.38$ in 24 specimens), which is assigned to Miogypsina intermedia of Drooger's mean V scale (Figures 5-7). The Kanayama Miogypsina population is found from the medium sandstone below the pumice tuff of the Yabuzuka Formation, and fission truck age of this tuff is $14.9 \pm 0.5$ Ma (Nomura et al., 2003). As such Miogypsinid foraminifera from the Obata, Idozawa and Yabuzuka Formations are known as Miogypsina globulina (Michelotti) and Miogypsina intermedia Drooger Assemblage. Raju (1974) and Mishra (1996) regarded Miogypsine globulina as population with mean V value between zero and 45 and positive $\gamma$, but Miogypsina intermedia couldn't find from the study of Indian Miogypsina. These criteria are arbitrary, and why they cannot find Miogypsina intermedia between Miogypsina globulina and Miogypsina cushmani or M. antillea in a series of mean V value scale? (Figure 7). 
Miogypsina nipponica Matsumaru is found from the middle member of the Kamiyokoze

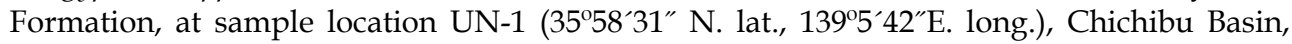
Saitama Prefecture (Matsumaru, 1980) (Figures 5-6). Also the planktonic foraminifera such as Globigerinoides immaturus (Leroy), Globigerinoides subquadratus Brönnimann, Globigerina praebulloides Blow, Globorotalia (Turborotalia) peripheroacuta Blow and Banner, and Globorotalia (Turborotalia) birnagea Blow are found from the upper member of the Kamiyokoze Formation

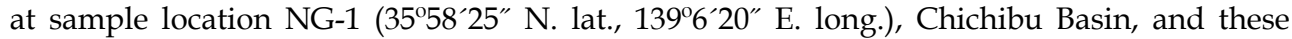
fauna is shown in the lower part of Zone N10 of Blow (1969) (Matsumaru, 1980). Miogypsina nipponica has the character of $\mathrm{V}$ value in 23 specimens (mean $\mathrm{V}=88.38 \pm 5.20$ ) and this mean $\mathrm{V}$ value is regarded as Miogypsina antillea (Cushman) step of Drooger (1952). V value of Miogypsina nipponica varies from 78 to 100 , and more than $42 \%$ of specimens having V value larger than 90. Then Miogypsina nipponica Matsumaru has both V value of Miogypsina cushmani (Cushman) step and M. antillea step of Drooger (1952). Raju (1974) regarded Miogypsina cushmani as miogypsinid population with mean V value between 70 and 100, usually less than 90, and more than $50 \%$ carrying less than 90. Also Miogypsina antillea has mean $\mathrm{V}$ value between 70 and 100, and more than $50 \%$ carrying greater than 90 .

Miogypsina nipponica resembles the topotype of Miogypsina antillea according to Cole (1957, pl. 29, fig. 1), but $M$. nipponica frequently possess small nepionic chambers on the deuteroconch (Matsumaru, 1980, pl. 25, figs. 4-5) (Plate 1, figure 10). The ogival to lozengic equatorial chambers and very short hexagonal equatorial chambers are sometimes distributed in Miogypsina nipponica, but the elongate hexagonal equatorial chambers are distributed in the frontal margins in Miogypsina antillea by Raju (1974, pl. 2, figs. 25-26). Miogypsina nipponica is distinguished from Miogypsina antillea by Frost and Langenheim (1974) in view of the description and illustration of Mexican specimens. In this study, Miogypsina nipponica is regarded as Miogypsina antillea step of $\mathrm{V}$ value, and associated with Miogypsina cushmani Vaughan and Miolepidocyclina (= Miogypsinita) japonica Matsumaru (Figure 7).

Miogypsina kotoi, which is junior synonym of Miogypsina globulina, is found from the Nakajima Formation, Dogo Island, Oki Islands (Matsumaru, 1982) (Figures 5-6). The sample location is Kumi at left side of the Kumi River about $1.1 \mathrm{~km}$ NW of Kumi Tunnel, Goka-

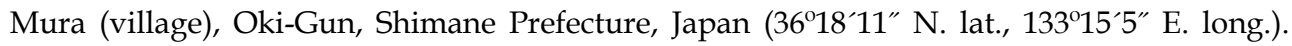
Miogypsina kotoi has the character of $\mathrm{V}$ value of 34 specimens (mean V = 31.29 \pm 11.0 ), and is in association with planktonic foraminifera such as Globorotalia acostaensis acostaensis Blow, G. continuosa Blow, G. quinifalcata Saito and Maiya, G. scitula (Brady), Globigerinoides quadrilobaturus Leroy and Globigerina sp. Then the geological age of the Nakajima Formation carrying Miogypsina kotoi is early Late Miocene based on Zone N16 (Blow, 1969). Therefore it is inferred from the planktonic foraminiferal zones that Miogypsina kotoi with low mean V value from the Nakajima Formation were reworked from the pre-Nakajima Formation. Moreover Miogypsina kotoi (= M. globulina) from the Nakajima Formation is associated with Miogypsina borneensis Tan Sin Hok, which is known to occur from the Lower/Middle Miocene sedimentary rocks in Japan in the Yatsuo Formation, Toyama Prefecture; and Hirashio Formation, Ibaraki Prefecture (Matsumaru and Takahashi, 2004).

Tania inokoshiensis Matsumaru is found from the sandstone of the Lower Formation ("Yamaga" Formation) of the Bihoku Group, Okayama prefecture (Matsumaru, 1990) (Figures 2, 5-7). The sample location is the same place as Hanzawa's (1935) and Tan Sin Hok's (1937) Inokoshi, Koyamaichi Village, Kawakami-Gun, Okayama Prefecture $\left(34^{\circ} 45^{\prime} \mathrm{N}\right.$. lat., $133^{\circ} 24^{\prime}$ E. long.) (Figures 5-6). Tania inokoshiensis Matsumaru is characterized by having 

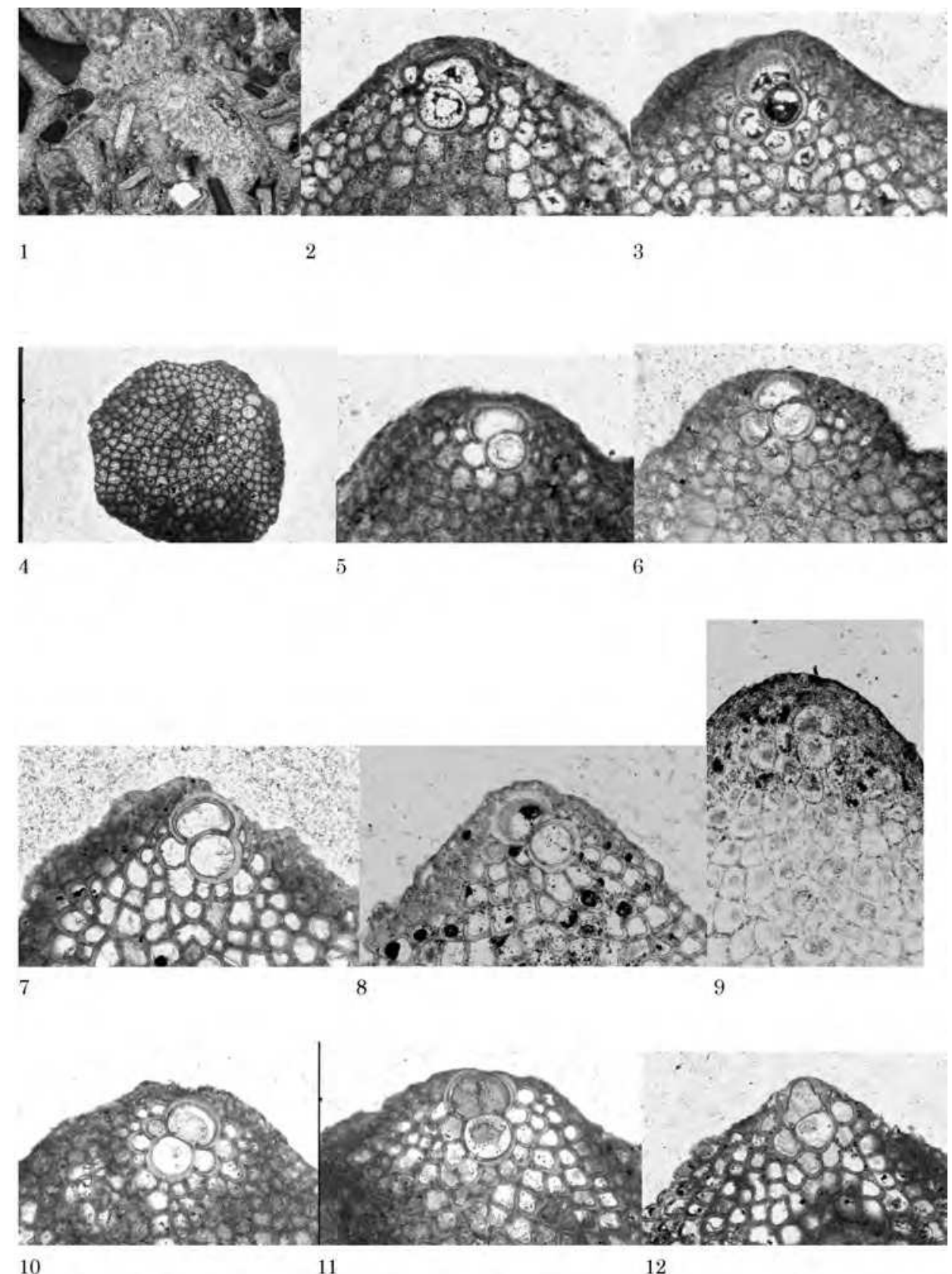

Plate 1.

Figures 1-5. Miogypsina globulina (Michelotti)

1. Centered oblique section. Topotype specimen of Miogypsina kotoi Hanzawa, 1931. 
Otsuki Limestone at Otsuki locality, Yamanashi Prefecture, Japan. x 19. 2-5. Equatorial sections. 2-3, 5. Miyato Formation, correlated with Obata Formation, at Komori locality, Saitama Prefecture, Japan, $x$ 53. 2: $V=25, \gamma=20^{\circ} .3 ; \mathrm{V}=29, \gamma=25^{\circ} ; 5: \mathrm{V}=40, \gamma=20^{\circ} ; 4$. Shiomizaki Formation at Todoroki locality, Aomori Prefecture, Japan. $x 19 . V=35, \gamma=35^{\circ}$. Figures 6-8. Miogypsina intermedia Drooger.

Equatorial sections. 6-7. Ichinokawa Formation, correlated with Idozawa Formation, at Kawabata locality, Saitama Prefecture, Japan. $x$ 53. 6: V =46, $\gamma=25^{\circ} ; 7: \mathrm{V}=48, \gamma=20^{\circ} .8$. Nakahara Formation at Hota locality, Chiba Prefecture, Japan. x 53. V =62, $\gamma=40^{\circ}$. Figure 9. Miogypsina cushmani Vaughan

Equatorial section. Yabuzuka Formation, correlated with Idozawa and/or Haratajino Formations, at Kanayama locality, Gunma Prefecture, Japan. $x 53 . \mathrm{V}=70, \gamma=10^{\circ}$.

Figures 10-12. Miogypsina nipponica Matsumaru

Equatorial sections. 10-12. Kamiyokoze Formation, at Une locality, Saitama Prefecture, Japan. $x$ 53. 10. $V=84, \gamma=30^{\circ}$ (This specimen possess Miogypsina cushmani step of V value, and small nepionic spirals on the outer wall of deuteroconch). 11. Holotype, Saitama Univ. coll. no. 800301, $\mathrm{V}=93, \gamma=5^{\circ} ; 12 . \mathrm{V}=90, \gamma=20^{\circ}$.

the peculiar structure of two unequal sets of spiral nepionic chambers, situated along the outer wall of deuteroconch, but not outer wall of protoconch, and having lozengic and short hexagonal shaped equatorial chambers and rectangular shaped lateral chambers (Plate 2, figures 8-9). Then Tania inokoshiensis represents more primitive arrangement of embryonic chambers and more advanced hexagonal equatorial chambers than each one of Miogypsina globulina, and is associated with Miogypsina globulina, which carry the character of V value (mean V = 44.31 in 37 specimens) at Inokoshi (Matsumaru and Takahashi, 2004). Tania inokoshiensis is similar to Lepidosemicyclina thecidaeformis due to having short hexagonal shaped equatorial chambers. But Tania inokoshiensis is different from Lepidosemicyclina thecidaeformis in having characteristic structure of two sets of spiral nepionic chambers developed along the outer wall of deuteroconch, but not along the outer wall of protoconch. Tania inokoshiensis is similar to Miogypsina primitiva Tan Sin Hok due to having deuteroconch situated on the frontal side of test and/or situated beside protoconch along the outer wall of protoconch. HoweverTania inokoshiensis is different from Miogypsona primitiva in having two sets of nepionic spirals along the outer wall of deuteroconch. The Miogypsina Sandstone of the Lower Formation, Bihoku Group is correlated with the Obata and Idozawa Formations, Tomioka Group due to similar mean value of parameter V of Miogypsina globulina. Moreover the Miogypsina Sandstone of the Lower Formation, Bihoku Group occurs Miolepidocyclina japonica Matsumaru, and is at lest correlated with the lower Zone 3 drill cores (ca. 209-146.63 $\mathrm{m}$ ) of the Kita Daitojima Limestone due to occurrence of Miogypsina (= Lepidosemicyclina) polymorpha (Rutten) with hexagonal equatorial chambers (Hanzawa, 1940) (Figures 6-7). Miolepidocyclina japonica is known to occur from the Lower/Middle Miocene Yatsuo Formation, Toyama Prefecture; Shiomizaki Formation, Aomori Prefecture; Saigo Formation, Shizuoka Prefecture; Naeshiroda Formation, Ibaraki Prefecture; Gassanzawa Sandstone, Yamagata Prefecture; Saginosu Formation, Saitama Prefecture; and Nakahara Formation, Chiba Prefecture, respectively. Their locations are shown in Honshu, Japan (Matsumaru and Takahashi, 2000, fig. 1).

7. Korkuteli Area, Bey Dağlari Autochton, Menderes - Taurus Platform, Turkey The Oligocene - Miocene succession of the Küçükkoy, Karabayir and Karakuştepe Formations is known to occur in the Bey Dağlari Autochton in the Menderes - Taurus Platform of main 

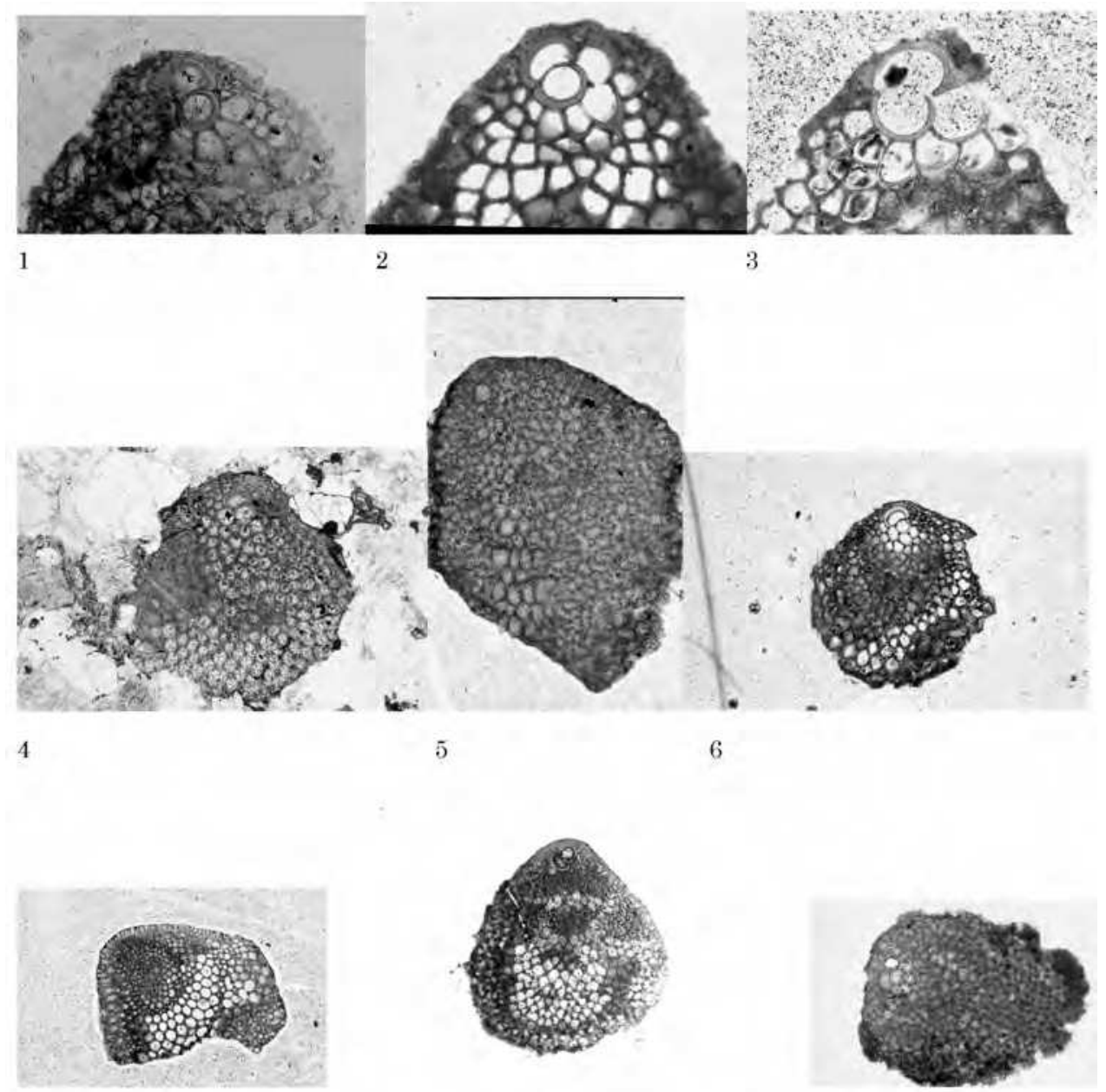

7

8

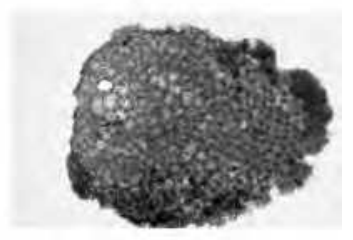

9

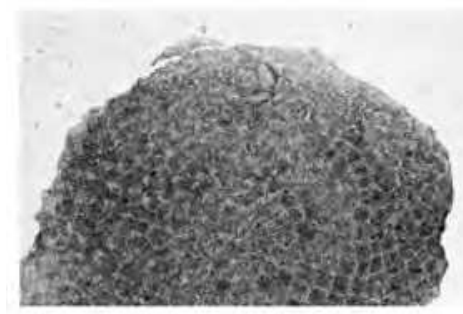

10

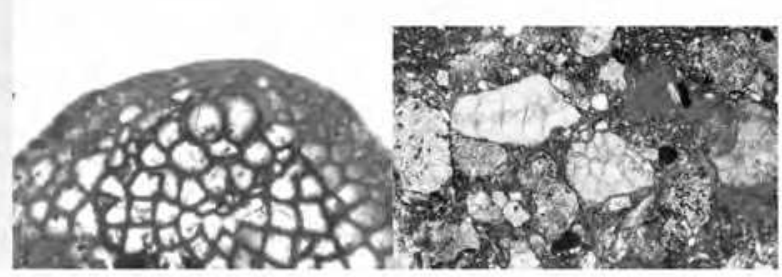

11

12

Plate 2.

Figures 1-3. Miogypsina borneensis Tan Sin Hok 
Equatorial sections. 1. Naeshiroda Formation at Tsukiori-Toge locality, Ibaraki Prefecture, Japan. $x=6, \gamma=25^{\circ} ; 2$. Nakajima Formation at Dogo locality, Shimane prefecture, Japan. $x=6, \gamma=-30^{\circ}$; 3. Hirashio Formation at Tanagura locality, Ibaraki Prefecture, Japan. $\mathrm{x}=6, \gamma=20^{\circ} . \mathrm{x} 53$.

Figure 4. Lepidosemicyclina musperi (Tan Sin Hok)

Equatorial section. Obata Formation at Nogami locality, Gunma Prefecture, Japan. x 19. Figures 5-7. Lepidosemicyclina thecidaeformis Rutten

Equatorial sections. 5-6. Megalospheric specimens, 5. Koguchi Formation at Kushimoto, Wakayama Prefecture, Japan, 6. Nakahara Formation at Hota locality, Chiba Prefecture, Japan. 7. Microspheric specimen. Nakahara Formation at Hota locality, Chiba prefecture, Japan. $\times 19$.

Figures 8-9. Tania inokoshiensis Matsumaru

Equatorial sections. 8-9. Lower ("Yamaga") Formation, Bihoku Group, at Inokoshi,

Okayama Prefecture, Japan. 8. Holotype, Saitama Univ. coll. no. 8803. x 19.

Figures 10-11. Miolepidocyclina japonica Matsumaru

Equatorial sections. 10. Gassanzawa Sandstone at Gassanzawa, Yamagata Prefecture, Japan. Holotype, Saitama Univ. coll. no. 720301. 11. Saigo Formation at Shinzaike locality, Shizuoka Prefecture, Japan. 10. x 19, 11. x 53.

Figure 12. Miogypsinoides dehaartii (van der Vlerk)

12 left. Axial section. 12 right. Oblique section. Shimizu Formation at Ashizuri Cape, Kochi Prefecture, Japan. x 19.

tectonic units, $40 \mathrm{~km} \mathrm{NW}$ Antalya City, Turkey (Figure 8). 13 columnar sections from Korkuteli to Karabayir Villages in Korkuteri area, Bey Dağlari Autochton are examined for Miogypsinid biostratigraphy (Matsumaru et al., 2010, figs. 1-3). As results, three larger foraminiferal assemblages are established as the following: Miogypsinoides formosensis Miogypsinoides bantamensis - Miogypsinoides dehaartii - Miogypsina primitiva - Spiroclypeus margaritatus Assemblage (Assemblage 1), Miogypsinoides bantamensis - Miogypsinoides dehaartii - Miogypsina primitiva - Miogypsina borneensis - Miogypsina globulina - Spiroclypeus margaritatus Assemblage (Assemblage 2), and Miogypsinoides dehaartii - Miogypsina borneensis - Miogypsina globulina - Miolepidocyclina burdigalensis Assemblage (Assemblage 3).

The Assemblage 1 is known from the Küçükkoy Formation, and 7 species of Miogypsinoides formosensis, Miogypsinoides bantamensis, Miogypsinoides dehaartii, Miogypsina primitiva Miogypsina borneensis, Lepidosemicyclina thecidaeformis, and Spinosemiogypsina antalyaensis Matsumaru, Özer and Sari are found in this Assemblage 1 (Figure 7). However two species of Paleomiogypsina boninensis Matsumaru and Miogypsinella complanata (Schlumberger) in the Assemblage 1 are considered to be reworked. The Assemblage 1 is a younger assemblage than Miogypsinella boninensis - Spiroclypeus margaritatus - Austrotrillina howchini Assemblage (Assemblage V) from the upper Minamizaki Limestone, Ogasawara Islands, Japan (Matsumaru, 1996). Because the Ogasawara assemblage (V) has the occurrence of Miogypsinella boninensis carrying primitive nepionic spirals and probable planktonic foraminifera belonging to Zone P22 than Zone P21 of Blow (1969) (Matsumaru, 1996) (Figures 6-7). Moreover the Assemblage 1 of Turkey is correlated with Zone 5 drill cores (431.67-ca.360 m) of the Kita Daitojima Limestone (Hanzawa, 1940) due to occurrence of Miogypsinella borodinensis (= Miogypsinoides formosensis) (Matsumaru et al., 2010). The measurement data of Miogypsinid foraminifera in the Assemblage 1 is as follows: A schizont specimen (A1 form; DI $=88 \times 92$ micron, DII $=96 \times 40$ micron)) of Miogypsinoides 
formosensis (Matsumaru et al., 2010, pl. 1, fig. 8) from locality 97-95 in Section 7 has the character of number of nepionic chambers $(X=13)$ and A-P angle $\left(\mathrm{AP}=210^{\circ}\right)$, while a schizont specimen (DI $=88 \times 96$ micron, DII $=96 \times 48$ micron) of Miogypsinoides formosensis (Matsumaru et al., 2010, pl. 1, fig. 9) from locality 97-96 in Section 7 has the character of number of nepionic chambers $(X=16)$ and A-P angle $\left(\mathrm{AP}=250^{\circ}\right)$. A gamont specimen (A2 form; DI $=160 \times 160$ micron, DII $=128 \times 48$ micron) of Miogypsinoides formosensis (Matsumaru e al., 2010, pl. 1, fig. 10) from locality 96-136 in Section 11 has the character of nepionic chambers $(X=13)$ and A-P angle $\left(A P=260^{\circ}\right)$, and also a schizont specimen (DI = $104 \times 112$ micron, DII = $84 \times 44$ micron) of Miogypsinoides bantamensis (Matsumaru et al., 2010, pl. 2, fig. 3) from locality 97-95 in Section 7, in associated with Miogypsinoides formosensis, has the character of number of nepionic chambers $(X=13)$ and A-P angle $(\mathrm{AP}=$ $180^{\circ}$ ). A gamont specimen (DI = $184 \times 168$ micron, DII $=192 \times 136$ micron) of Miogypsinoides bantamensis (Matsumaru et al., 2010, pl. 2, fig. 4) from locality 96-137 in Section 11, associated with Miogypsinoides formosensis, has the character of number of nepionic chambers $(X=11)$ and A-P angle $\left(\mathrm{AP}=150^{\circ}\right)$. A gamont specimen $(\mathrm{DI}=136 \times 120$ micron, $\mathrm{DII}=128 \times 80$ micron) of Miogypsinoides bantamensis (Matsumaru et al., 2010, pl. 2, fig. 5) from locality 96137 in Section 11 has the character of number of nepionic chambers $(X=10)$ and A-P angle $\left(\mathrm{AP}=150^{\circ}\right)$. Moreover on Miogypsinoides dehaartii, associated with Miogypsinoides formosensis and Miogypsinoides bantamensis, a gamont specimen (DI $=152 \times 116$ micron, DII $=168 \times 88$ micron; Matsumaru et al., 2010, pl. 2, fig. 7) from locality 97-95 in Section 7 has the character of number of nepionic chambers $(X=9)$ and A-P angle $\left(\mathrm{AP}=60^{\circ}\right)$, while a gamont specimen (DI = $176 \times 168$ micron, DII = $208 \times 160$ micron; Matsumaru et al., 2010, pl. 2, fig. 8) from locality 96-119 in Section5 has the character of nepionic chambers $(X=7)$ and A-P angle (AP $=50^{\circ}$ ). A gamont specimen (DI = $224 \times 200$ micron, DII = $244 \times 112$ micron; Matsumaru et al., 2010, pl. 3, fig. 6) from locality 97-95 in Section 7 has the character of number of nepionic chambers $(\mathrm{X}=10)$ and A-P angle $\left(\mathrm{AP}=60^{\circ}\right)$.

On Miogypsina primitiva, associated with Miogypsinoides formosensis, Miogypsinoides bantamensis and Miogypsinoides dehaartii, a schizont specimen (DI $=84 \times 88$ micron, DII $=72$ $x 56$ micron) from locality 97-95 in Section 7 has the character of nepionic chambers $(X=12)$ and A-P angle (AP = obscure due to twist) (Matsumaru et al., 2010, pl. 3, fig. 4), while a gamont specimen $(\mathrm{DI}=200 \times 176$ micron, $\mathrm{DII}=176 \times 128$ micron) from locality 97-95 in Section 7 has the character of nepionic chambers $(X=10)$ and A-P angle $\left(A P=110^{\circ}\right)$ (Matsumaru et al., 2010, pl. 3, fig. 5).

The Assemblage 2 is known from the Karabayir Formation, and 6 species of Miogypsinoides bantamensis, Miogypsinoides dehaartii, Miogypsina primitiva, Miogypsina borneensis, Miogypsina globulina and Lepidosemicyclina thecidaeformis are found from the Assemblage 2 (Figur 7). The Assemblage 2 is correlated with lower Zone 4 drill cores (ca. 360-302.31 m) of the Kita Daitojima Limestone (Hanzawa, 1940) due to occurrence of Miogypsinoides bantamensis, Miogypsinoides lateralis, and Miogypsinoides dehaartii var. pustulosa $(=M$. dehaartii) (Matsumaru et al., 2010). The measurement data of Miogypsinid foraminifera of the Assemblage 2 is described as follows: a schizont specimen (DI $=112 \times 96$ micron, DII $=120 \times$ 72 micron) of Miogypsinoides bantamensis (Matsumaru et al., 2010, pl. 2, fig. 2) from locality 96-121 in Section 5 has the character of number of nepionic chambers $(X=12)$ and A-P angle $\left(\mathrm{AP}=180^{\circ}\right)$. On Miogypsina primitiva, two specimens are measured: a schizont specimen (DI $=96 \times 72$ micron, DII = $88 \times 40$ micron) from locality 97-90 in Section 8 has the character of nepinic chambers $(X=11)$ and A-P angle $\left(A P=145^{\circ}\right)$ (Matsumaru, 2010, pl. 3, fig. 2), and a 
schizont specimen (DI = $96 \times 90$ micron, DII = $88 \times 64$ micron) from locality 97-153 in Section 4 has the character of nepionic chambers $(X=9)$ and A-P angle $\left(\mathrm{AP}=110^{\circ}\right)$ (Matsumaru et al., 2010, pl. 3, fig. 3). On Miogypsiona borneensis, three specimens are measured: a gamont specimen $(\mathrm{DI}=120 \times 112$ micron, DII $=128 \times 84$ micron) from locality 97-90 in Section 8 has the character of nepionic chambers $(X=8)$ and A-P angle $\left(\mathrm{AP}=50^{\circ}\right)$ (Matsumaru et al., 2010, pl. 3, fig. 9). A gamont specimen (DI $=120 \times 116$, DII $=140 \times 83$ micron) from locality 97-152 in Section 4 has the character of nepionic chambers $(X=7)$ and A-P angle (AP $\left.=25^{\circ}\right)$ (Matsumaru et al., 2010, pl. 3, fig. 10), while a schizont specimen (DI $=96 \times 72$, DII $=88 \times 40$ micron) from locality 97-90 in Section 8 has the character of nepionic chambers $(\mathrm{X}=7)$ and A-P angle $(\mathrm{AP}=$ $20^{\circ}$ ) (Matsumaru et al., 2010, pl. 4, fig. 1). Also a schizont specimen (DI $=128 \times 104, \mathrm{DII}=144 \mathrm{x}$ 80 micron) of Miogypsina globulina from locality 97-90 in Section 8 shows the character of V value $(\mathrm{V}=30)$ and $\gamma$ value $\left(\gamma=10^{\circ}\right)$ (Matsumaru et al., 2010, pl. 4, fig. 7).

The Assemblage 3 is known from the Karakuştepe Formation, and 5 species of Miogypsinoides dehaartii, Miogypsinopides borneensis, Miogypsina globulina, Miolepidocyclina burdigalensis and Lepidosemicyclina thecidaeformis are found from the Assemblage 3 (Figure 7). The Assemblage 3 is correlated with upper Zone 4 drill cores (302.31 - ca. $209 \mathrm{~m})$ of the Kita Daitojima Limestone (Hanzawa, 1940) due to occurrence of Miogypsinoides dehaartii var. pustulosa ( = M. dehaartii) and Miogypsina borneenisis (Matsumaru et al., 2010). In the Assemblage 3, the following Miogypsinid foraminifera are measured: On Miogypsina globulina, two specimens are measured; a gamont specimen (DI $=200 \times 136$, DII $=216 \times 120$ micron) from locality 97-142 in Section 4 has the character of $\mathrm{V}$ value $(\mathrm{V}=35)$ and $\gamma$ value $(\gamma$ $=40^{\circ}$ ) (Matsumaru et al., 2010, pl.4, fig. 5), and a gamont specimen (DI $=176 \times 152, \mathrm{DII}=248$ $x 152$ micron) from locality 97-125 in Section 4 has the character of $V$ value $(V=25)$ and $\gamma$ value $\left(\gamma=34^{\circ}\right)$ (Matsumaru et al., 2010, pl. 4, fig. 6).

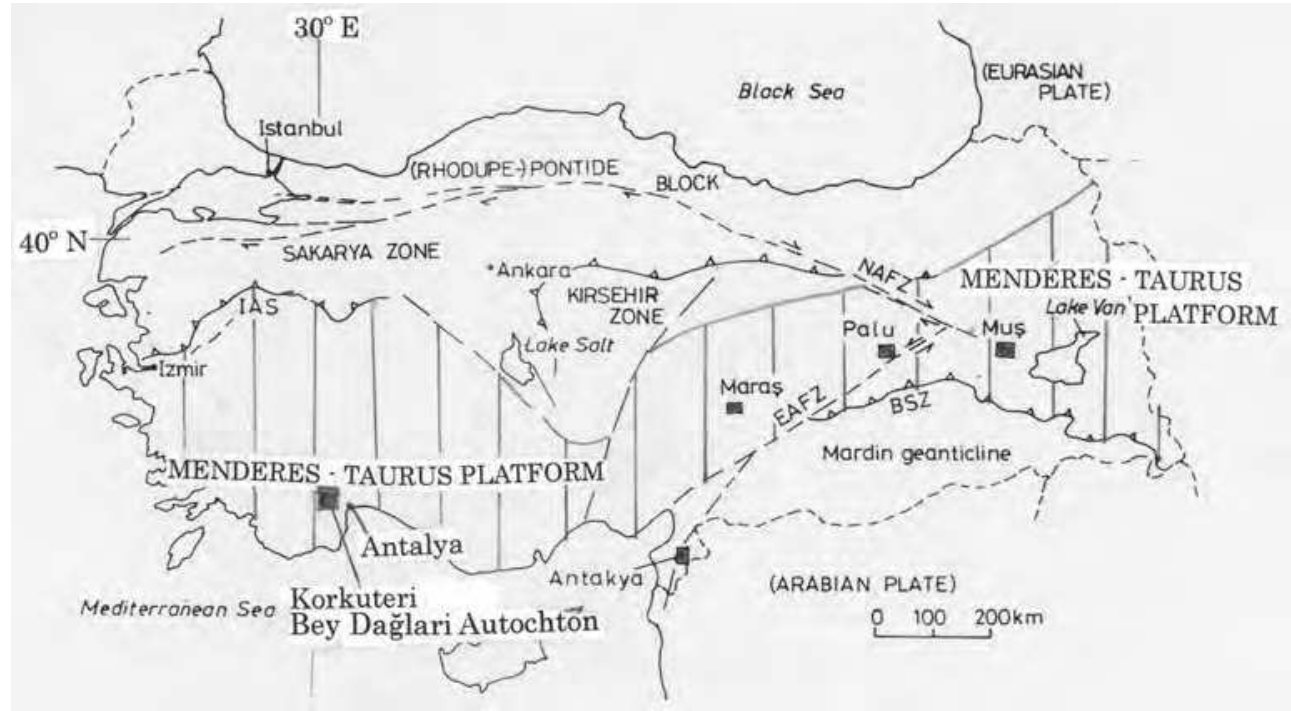

Fig. 8. Locations of research areas (Maraş Palu and Muş) in Turkey treated in this study, in addition to Korkuteri area (Matsumaru et al., 2010). Antakya area without Miogypsinid samples is described in the text. 


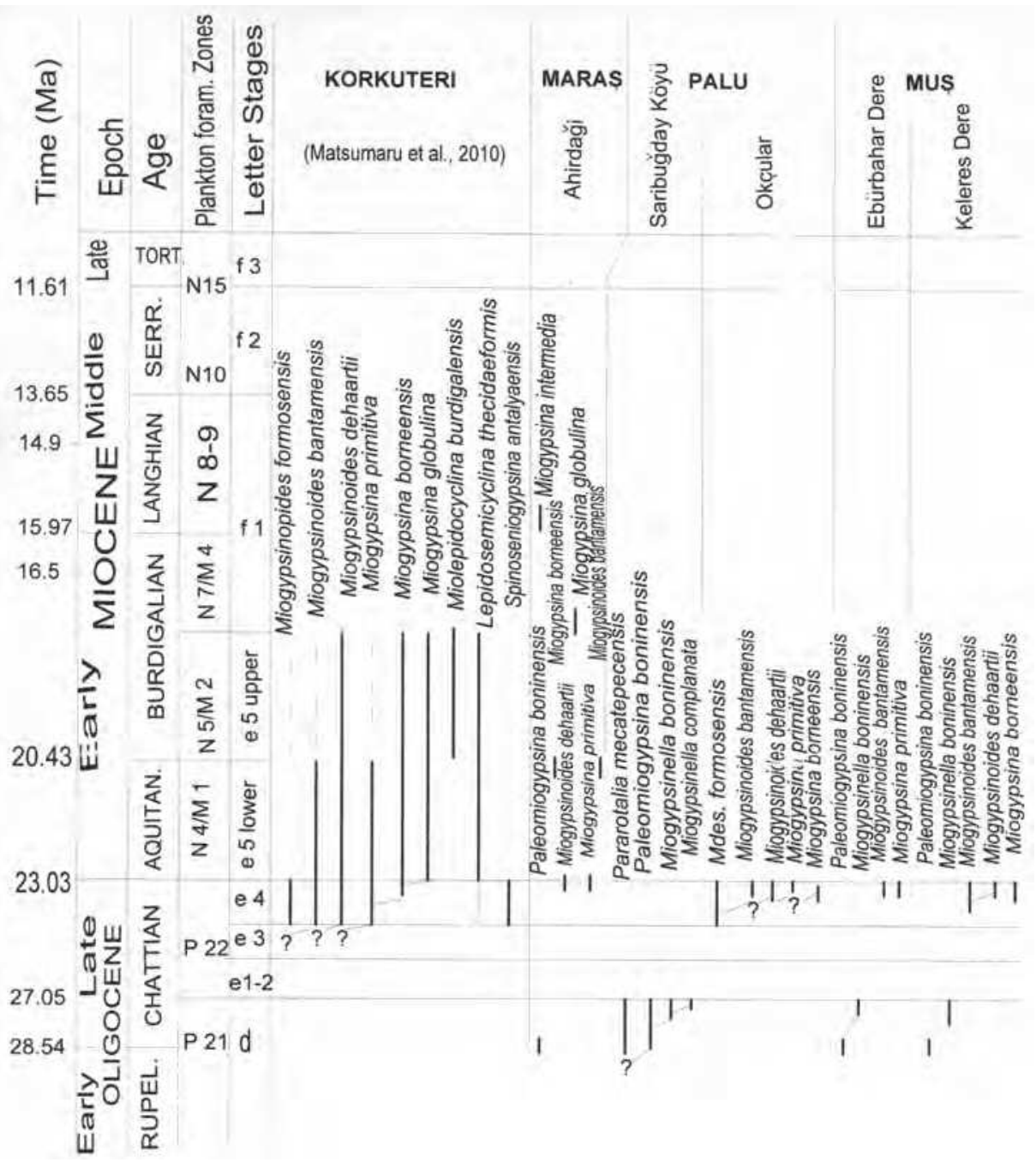

Fig. 9. Biostratigraphic occurrence of Miogypsinid foraminifera from Korkuteri, Maraş, Palu, and Muş areas in the Menderes - Taurus Platform, Turkey.

\section{Biostratigraphic occurrence of Miogypsinid foraminifera from Maraş, Palu and Muş areas in the Menderes - Taurus Platform, Turkey}

While the author has visited the General Directorate of Mineral Resaerch and Exploration (MTA; T.C. Maden Tetkik Ve Arma Genel Müdürlüğü), Ankara as the Japan Society for the Promotion of Science (JSPS) fellowship researcher for a half year in 1992, he has investigated the foraminifers from the upper Cretaceous to middle Miocene sedimentary rocks in Turkey. This study is to give a note on Miogypsinid foraminiferal Biostratigraphy of Maraş, Palu, and Muş Areas in the eastern Turkey after Uysal et al. (1985), except Antakya Area due to lack of 
Miogypsinid foraminifera-bearing samples, where Nummulites fabianii (Prever), N. perforatus (Montfort), Pellatispira orbitoidea (Provale) and others are found from samples A-1 to A-8. Here the author describes useful scientific contribution for Miogypsinid foraminifera (Figures 8-9).

1. Ahirdaği Section, Maraş Area

According to Uysal et al (1985), there are four columnar sections in Maraş Area. In Ahirdaği section in this study, there are five Miogypsinid horizons. Basal samples 77/59 to 77/57 yield Paleomiogypsina boninensis Matsumaru, Lepidocyclina boetonensis van der Vlerk, carrying the character $(\mathrm{DI}=300 \times 188$ micron, DII $=390 \times 223$ micron, and DI $=305 \times 200$ micron, DII $=335 \times 215$ micron, and thickness of embryonic wall $(\mathrm{T}=12$ micron $))$ in two specimens, Nephrolepidina marginata (Michelotti), Heterostegina borneensis van der Vlerk, carrying the character (1 or 2? operculine chamber(s) and 19 to 20 nepionic septa), and Cycloclypeus koolhoveni Tan Sin Hok, carrying the character (more than 23 and 25 heterostegine septa, and $\mathrm{DI}=118 \times 118$ micron), and Eulepidina dilatata (Michelotti). They are regarded as the age of late Early to early Late Oligocene. Also they are assigned to probable Tertiary d of the Letter Satges (Leupold and van der Vlerk, 1931; Matsumaru, 1996), because of the occurrence of Paleomiogypsina boninensis, Heterostegina borneensis, and Eulepidina ephippioides, which are dominated in the Minamizaki Limestone, Ogasawara Islands, Japan (Matsumaru, 1996) (Figures 6-7). Moreover Paleomiogypsina boninensis in the Assemblage 1 was found in samples 97-486, 97-502, and 97-503 from the Küçükkoy Formation in the Korkuteri Area, Bey Dağlari Autochton, but Paleomiogypsina boninensis was regarded as the reworked species in those samples as stated before (Matsumaru et al., 2010, pl. 1, figs. 1-4) (Figure 9). Sample 77/60, 10 m below from Sample 77/59, yields Eulepidina dilatata, Lepidocyclina boetonensis van der Vlerk, carrying the character (DI $=320 \times 220$ micron, DII $=325 \times 125$ micron, and 6 nepionic spirals), Nephrolepidina marginata, and Heterostegina borneensis, carrying the character ( 1 operculine chambers, 8 chambers in 1 whorl, and 21 chambers in 2 whorls), although there is no Miogypsinid foraminifera, but it is worth to describe the fauna.

More than $40 \mathrm{~m}$ above from sample 77/57, sample E479 in Ahirdağgi Section yields Miogypsinoides dehaartii (van der Vlerk), carrying number of nepionic chambers $(X=7)$, Miogypsina primitiva Tan Sin Hok, carrying the character $(X=9)$, Elphidium spp., and Planorbulinella larvata (Parker and Jones). This horizon is probable assigned to the boundary between the Oligocene and Miocene, due to occurrence of Miogypsinoides dehaartii and Miogypsina primitiva based on foraminiferal biostratigraphic occurrences between the Küçükkoy and Karabayir Formations, Korkuteri Area (Matsumaru et al., 2010) (Figures 6-7, 9). Above 90 m from sample E479, Sample E477 occurs Miogypsina borneensis Tan Sin Hok, carrying the character ( $\mathrm{X}=6$ to 8 ), and Miogypsinoides bantamensis (Tan Sin Hok), carrying the character $(X=14)$, and Elphidium spp. This horizon is correlated with the Karabayir Formation due to occurrence of Miogypsinoides bantamensis and Miogypsina borneensis, and then the age of the horizon is assigned to the Early Miocene (Aquitanian) (Figure 9).

Sample E475, at about $50 \mathrm{~m}$ above from sample E477, yields Miogypsina globulina and Operculina complanata (Defrance). Miogypsina globulina with 11 specimens has been measured, and they are the character of the followings: DI $=108 \times 108$ micron, DII $=150 \times$ 125 micron, DII/DI $=1.39, \mathrm{~V}=40.7, \gamma=40^{\circ} ; \mathrm{DI}=200 \times 163$ micron, DII $=238 \times 175$ micron, $\mathrm{DII} / \mathrm{DI}=1.29, \mathrm{~V}=37.0, \gamma=10^{\circ} ; \mathrm{DI}=165 \times 140$ micron, $\mathrm{DII}=173 \times 103$ micron, DII $/ \mathrm{DI}=1.05$, $\mathrm{V}=43.5, \gamma=15^{\circ}$; DI $=148 \times 105$ micron, DII $=198 \times 118$ micron, DII $/ \mathrm{DI}=1.34, \mathrm{~V}=29.6, \gamma=$ $5^{\circ}$; DI = $165 \times 135$ micron, DII = $207 \times 116$ micron, DII $/ \mathrm{DI}=1.25, \mathrm{~V}=38.5, \gamma=30^{\circ}$; DI $=140 \mathrm{x}$ 130 micron, $\mathrm{DII}=210 \times 125$ micron, $\mathrm{DII} / \mathrm{DI}=1.50, \mathrm{~V}=44.4, \gamma=15^{\circ} ; \mathrm{DI}=125 \times 123$ micron, $\mathrm{DII}=163 \times 125$ micron, $\mathrm{DII} / \mathrm{DI}=1.30, \mathrm{~V}=40.0, \gamma=25^{\circ} ; \mathrm{DI}=168 \times 166$ micron, $\mathrm{DII}=235 \times$ 
123 micron, DII $/ \mathrm{DI}=1.39, \mathrm{~V}=37.0, \gamma=20^{\circ}$; DI $=175 \times 140$ micron, DII $=240 \times 150$ micron, $\mathrm{DII} / \mathrm{DI}=1.37, \mathrm{~V}=34.8, \gamma=20^{\circ} ; \mathrm{DI}=118 \times 108$ micron, $\mathrm{DII}=125 \times 116$ micron, $\mathrm{DII} / \mathrm{DI}=1.06$, $\mathrm{V}=33.3, \gamma=15^{\circ}$, and DI $=145 \times 165$ micron, $\mathrm{DII}=213 \times 116$ micron, DII $/ \mathrm{DI}=1.47, \mathrm{~V}=30.4$, $\gamma=25^{\circ}$. Miogypsina globulina is generally characterized by the data of mean $\mathrm{V}$ of 37.2 and mean $\gamma$ of $20^{\circ}(\mathrm{n}=11)$, and is regarded as the form of the stratigraphic position between $M$. globulina of Tungliang Well TL1, Taiwan (mean V $=23.58$, mean $\gamma=15^{\circ}, \mathrm{n}=4$ ) and $M$. globulina of Nogami Area, Obata Formation, Tomioka Group, Japan (mean V = 43.93, mean $\gamma$ $=40^{\circ}, \mathrm{n}=20$ )(Figures 6-7). Therefore the age of Miogypsina globulina from sample E475 is probably situated in Early Miocene (Burdigalian) (Figure 9).

Sample E471, about $20 \mathrm{~m}$ above from sample E475, yields Miogypsina intermedia Drooger, which has the character such as DI $=173 \times 148$, DII $=175 \times 75$ micron, DII/DI $=1.01, \mathrm{~V}=49$, and $\gamma=30^{\circ}$. As such Miogypsina intermedia from sample E475 is correlated with M. intermedia, associated with M. globulina from the Obata and Idozawa Formations, Tomioka Group, and other Japanese Miocene sedimentary rocks, i.e. Yabuzuka Formation in Ota City (Matsumaru and Takahashi, 2000) (Figures 6-7). The age of M. intermedia bearing sample E471 horizon is assigned to the Middle Miocene (Langhian) (Figure 9).

2. Saribuğday Köyü Section, Palu Area

Sample M230 in Saribuğday Köyü Section, Palu Area (Uysal et al., 1985) yields Pararotalia mecatepecensis (Nuttall), Paleomiogypsina boninensis Matsumaru, Nummulites fichteli Michelotti, Lepidocyclina isolepidinoides van der Vlerk, Eulepidina dilatata (Michelotti), Borelis pygmaeus (Hanzawa), and Austrotrillina spp. As such this fauna is correlated with the fauna of samples $77 / 59$ to $77 / 57$ in Ahirdaği Section, Maraş Area, as stated above, due to occurrence of Paleomiogypsina boninensis (Figure 9). As the author has described the evolution from Pararotalia mecatepecensis (Nuttall) to Paleomiogypsina boninensis Matsumaru, both species could be found in sample M230 (Matsumaru, 1996, p. 56, fig. 24) (Figure 4). The basal Sample M224, about $740 \mathrm{~m}$ below from Sample M230, yields Lepidocyclina isolepidinoides van der Vlerk, carrying the character (DI $=163 \times 110$ micron, DII $=175 \times 105$ micron, and 6 nepionic spirals), Eulepidina dilatata, Nummulites fichteli, N. vascus Joly and Leymerie, and Borelis pygmaeus (Hanzawa), and is regarded as the basal Tertiary d of the Letter Stages, although there is no miogypsinid foraminifera. However it is worth to describe the basal Oligocene in this area.

Sample M232, about $40 \mathrm{~m}$ above from sample M230, yields Miogypsinella boninensis carrying the character $(X=23, \mathrm{DI}=110 \times 90$ micron, and DII $=90 \times 60$ micron), Nummulites fichteli, Nephrolepidina marginata, Eulepidina dilatata, Borelis pygmaeus, Heterostegina spp., Halkyardia minima (Liebus), and Operculina spp. Top sample M233, about $130 \mathrm{~m}$ above from sample M232, yields Miogypsinella boninensis, carrying the character $(X=26, \mathrm{DI}=110 \times 95$ micron, and DII = $85 \times 40$ micron), Miogypsinella complanata (Schlumberger), carrying the character $(\mathrm{X}=$ more than 18, DI $=110 \times 103$ micron, and DII = $88 \times 30$ ? micron), Paleomiogypsina boninensis, Pararotalia mecatepecensis, and rarely Nummulites fichteli. Therefore these fauna from three samples (M230, M232, and M233) are correlated with the Assemblage IV from the Minamizaki Limestone due to occurrence of Paleomiogypsina boninensis, Miogypsinella boninensis, Eulepidina dilatata, Nephrolepidina marginata, Borelis pygmaeus, and Halkyardia minima (Matsumaru, 1996). Then these fauna from Saribuğday Köyü is assigned to Tertiary d stage of the Letter Stages. Nummulites fichteli is known in the fauna from Saribuğday Köyü, but isn't known in the Assemblage IV from Ogasawara Islands. Also Miogypsinella complanata carrying the number of nepionic chambers $(X=$ more than 18$)$, is known to occur from the fauna of Saribuğday Köyü, but this species isn't known in association with Nummulites fichteli in the Tethys region as far as the author knows. Then Nummulites fichteli in sample M233 is considered to be reworked, and 
the fauna of sample M233 may be partly correlated with the Assemblage V from the uppermost Minamizaki Limestone, Ogasawara Islands, Japan (Matsumaru, 1996).

3. Okçülar Section, Palu Area

Sample 77/27B below the basalt layer in the Okçülar Section, Palu Area (Uysal et al., 1985) yield Miogypsinoides formosensis (Yabe and Hanzawa), carrying the character $(X=15, D I=$ $116 \times 110$ micron, DII = $95 \times 63$ micron, and AP = 210 $)$, Eulepidina dilatata, Nephrolepidina marginata (Michelotti), Cycloclypeus spp. and Operculina complanata (Defrance). The fauna of sample $77 / 27 \mathrm{~B}$ is correlated with the Assembalge 1 of the Küçükkoy Formation in the Korkuteri Area due to occurrence of Miogypsinoides formosensis (Matsumaru et al., 2010). In sample $77 / 27 \mathrm{~B}$, Miogypsinella complanata, carrying the character $(X=$ more than $18, D I=100$ x 88 micron, and DII $=75 \times 50$ micron) is, however, found in association with Miogypsinoides formosensis, but Miogypsinella complanata is considered to be reworked.

Sample 77/26 above the same basalt layer yield Miogypsinoides formosensis, Spiroclypeus spp., Heterostegina spp., and Operculina complanata, in addition to Nummulites vascus Joly and Leymerie, which is characterized by having the character (DI $=100 \times 98$ to $263 \times 193$ micron, $\mathrm{DII}=83 \times 40$ to $208 \times 108$ micron, distance and number of chambers in $1 / 2$ whorl $=360$ to 400 micron and 3, those in 1 whorl $=825$ to 875 micron and 8 , those of $11 / 2$ whorl $=1125$ to 1200 and 13 to 17, and those in 2 whorl = 1405 to 1475 micron and 20 to 24), Cycloclypeus koolhoveni Tan Sin Hok, carrying the character (DI = $125 \times 125$ to $120 \times 118$ micron, DII $=168 \times 73$ to $175 \times$ 58 micron, number of opeculine chamber $=3$, and number of nepionic septa $=$ more than 16 ), and Miogypsinella complanata, carrying the character ( DI $=88 \times 78$ micron, DII $=72 \times 38$ micron, and $X=19)$, respectively. The latter three species of Nummulites vascus, Cycloclypeus koolhoveni, and Miogypsinella complanata are considered to be reworked due to non coexistence.

Sample 77/20, about 50m above from Sample 77/26, yield Miogypsinoides dehaartii, carrying the character $(X=6, D I=145$ micron, DII $/ \mathrm{DI}=1.14 ; \mathrm{X}=6, \mathrm{DI}=153 \times 125$ micron, $\mathrm{DII}=150 \mathrm{x}$ 123 micron, DII/DI $=0.98$; and $X=7, \mathrm{DI}=175$ micron, DII/DI $=0.74)$ in three specimens, Miogypsina borneensis, carrying the character $\left(X=6, D I=145 \times 125\right.$ micron, $\gamma=40^{\circ}$; and $X=7$, $\mathrm{DI}=175 \times 175$ micron, DII $=130 \times 63$ micron, $\left.\gamma=40^{\circ}\right)$ in two specimens, Eulepidina dilatata, Nephrolepidina marginata, and Operculina complanata. Sample 77/19, $20 \mathrm{~m}$ above from Sample 77/20 yields Miogypsinoides dehaartii, Operculina complanata, and Cycloclypeus spp., in addition to Paleomiogypsina boninensis, and Miogypsinella ubaghsi (Tan Sin Hok), carrying the character $\left(X=24, \mathrm{DI}=63 \times 58\right.$ micron, $\mathrm{DII}=50 \times 43$ micron, $\mathrm{AP}=425^{\circ}$, and diameter of spiral chambers $=650 \times 763$ micron). The latter two species are considered to be reworked, but the discovery of Miogypsinella ubaghsi is important to consider the evolutional lineage from Miogypsinella boninensis to Miogypsinella ubaghsi based on Tan Sin Hok's nepionic acceleration (Figure 4). This lineage has been considered as the evolution from Miogypsinella boninensis in the Assemblage $\mathrm{V}$ of the Minamizaki Limestone, Ogasawara Islands to Miogypsinella ubaghsi in the dredge limestones of the Komahashi-Daini Seamount, Kyushu Palau Ridge as stated before (Figure 6-7).

Sample 77/18, about $20 \mathrm{~m}$ above from Sample 77/19 yields Miogypsinoides formosensis, carrying the character $\left(X=16, \mathrm{DI}=65 \times 45\right.$ micron, $\mathrm{DII}=112 \times 80$ micron, and $\left.\mathrm{AP}=270^{\circ}\right)$, Miogypsinoides bantamensis (Axial section), Miogypsina primitiva, carrying the character $(\mathrm{X}=$ 11 , DI $=125 \times 116$ micron, DII $=138 \times 78$ micron, and $\left.\mathrm{AP}=160^{\circ}\right)$, Heterostegina spp., carrying the character (DI $=230 \times 200$ micron, and number of operculine chambers $=3$ ), and Planorbulinella larvata (Parker and Jones). Moreover Sample 77/16, about $40 \mathrm{~m}$ above from Sample 77/18, yields probable Miogypsinoides formosensis, Heterostegina spp., Cycloclypeus spp, and Operculina complanata, and is overlain by the basalt. In this section, all samples 
treated in the study belong to upper Oligocene and can be correlated with the Küçükkoy Formation in Korkuteri Area (Figure 9).

4. Ebürbahar Dere Section, Muş Area

Sample M27 in the Ebürbahar Dere, Muş Area (Uysal et al., 1985) yields Paleomiogypsina boninensis, carrying the character $(\mathrm{DI}=125 \times 125$ micron, $\mathrm{DII}=130 \times 83$ micron, 17 to 20 spiral chambers in 2 whorls, and diameter of nepionic spirals $=900$ to 1050 micron), Nephrolepidina marginata (Michelotti), Borelis pygmaeus, Operculina spp., and Peneroplis spp. This sample is a horizon about $800 \mathrm{~m}$ above from the boundary between the Eocene and Oligocene sedimentary rocks, and is correlated with Samples 77/59 to 77/ 57 in the Ahirdaği Section, Maraş Area, and Sample M230 in the Saribuğday Köyü Section, Palu Area, due to occurrence of Paleomiogypsina boninensis (Figure 9). Sample M5, about $722 \mathrm{~m}$ above from Sample M27 yields Miogypsinella boninensis, carrying the character (DI $=70 \times 50$ micron, and diameter of nepionic spirals $=745$ micron), Eulepidina dilatata, Nephrolepidina spp., and Spiroclypeus spp. This horizon is correlated with Samples M 232 and M233 in Saribuğday Köyü Section, Palu Area, due to occurrence of Miogypsinella boninensis (Figure 9). Moreover Sample M1, about $450 \mathrm{~m}$ above from Sample M5 yields Miogypsinoides bantamensis, carrying the character (dimension of protoconch (diam. $x$ height.) of $223 \times 208$ micron, and dimension of deuteroconch (diam. $x$ height.) of $175 \times 118$ micron in axial section, and form ratio of diameter/thickness (F. R. $=1.5$ $\mathrm{mm} / 0.58 \mathrm{~mm}=2.61)$ ), Miogypsina primitiva, carrying the character $(X=$ more than $10, \mathrm{DI}=183$ x 175 micron, and DII = $173 \times 123$ micron), Eulepidina dilatata, Heterostegina spp., carrying the character $(\mathrm{DI}=318 \times 283$ micron, DII $=365 \times 188$ micron, and 7 nepionic chambers in 1 whorl), and Spiroclypeus spp. This fauna from Sample M1 is correlated with the fauna of Sample 77/18 in the Okçülar Section, Palu Area, due to occurrence of Miogypsinoides bantamensis and Miogypsina primitiva (Figure 9).

5. Keleres Dere Section, Muş Area

Sample O155 in the Keleres Dere Section, Mus Area (Uysal et al., 1985) yields Paleomiogypsina boninensis, carrying the character $(X=$ more than $20, D I=110 \times 108$ micron, and DII $=112 \times 58$ micron), Heterostegina spp., Borelis pygmaeus, Peneroplis spp. and Austrotrillina spp. This fauna is correlated with the fauna of Sample M27 in the Ebürbahar Dere Section, Muş Area; Sample M230 in the Saribuğday Köyü Section, Palu Area; and Samples 77/59 to 77/57 in the Ahirdaği Section in Maraş Area, due to occurrence of Paleomiogypsina boninensis, respectively. Sample O148, placed about $310 \mathrm{~m}$ thick above from Sample O155 yields Miogypsinella boninensis, Heterostegina spp. and Planorbulinella larvata. Sample 142, placed more than $1000 \mathrm{~m}$ above from Sample O148, yields Miogypsenella boninensis, carrying the character $(X=$ more than 23, DI $=$ $110 \times 105$ micron, DII = $112 \times 73$ micron, and diameter of nepionic spirals $=865$ micron), and Operculina complanata, carrying the character (DI $=250 \times 208$ micron, DII $=238 \times 135$ micron, and distance and number of chambers in $1 / 2$ whorl $=700$ micron and 3 , those in 1 whorl $=$ 1125 micron and 8, those in $11 / 2$ whorl $=1400$ micron and 18, and those in 2 whorl $=3700$ micron and 28). The fauna from Samples O148 to M142 is correlated with the fauna of Samples M232 to M233 in the Saribuğday Köyü Section, Palu Area, due to occurrence of Miogypsinella boninensis, respectively.

Sample M139, placed about $650 \mathrm{~m}$ above from Sample M142, yields Miogypsinoides bantamensis, carrying the character $(X=12, \mathrm{DI}=118 \times 120$ micron, DII $=100 \times 60$ micron, and diameter of nepionic spirals $=600$ micron), Spiroclypeus spp., Eulepidina dilatata, and Lepidocyclina boetonensis van der Vlerk. Sample M133, placed about $300 \mathrm{~m}$ above from Sample M139, yields Miogypsina borneensis, carrying the character $(X=7, D I=171 \times 170$ micron, DII $=190 \times 100$ micron, $\gamma=30^{\circ}$, and diameter of nepionic spirals $=625$ micron), 
Heterostegina spp., and Operculina complanata. Sample M131, placed obscure rightly, but about $60 \mathrm{~m}$ thick above from Sample M133, yields Miogypsinoides bantamensis, carrying the character $\left(X=11\right.$, DI $=113 \times 105$ micron, DII $=113 \times 75$ micron, $\gamma=20^{\circ}$, and diameter of nepionic spirals $=525$ micron, and $\left.\mathrm{AP}=170^{\circ}\right)$, Miogypsinoides dehaartii, carrying the character $\left(\mathrm{X}=6, \mathrm{DI}=158 \times 113\right.$ micron, DII $=158 \times 105$ micron, and $\left.\gamma=20^{\circ}\right)$, and Miogypsina borneensis, carrying the character $\left(X=7, D I=135 \times 120\right.$ micron, $D I I=150 \times 85$ micron, and $\left.\gamma=20^{\circ}\right)$. As such the fauna of Samples M139 to M131 is correlated with the fauna of Sample M1 in the Ebürbahar Dere Section, Muş Area; and Samples 77/20 to 77/18 in the Okçülar Section, Palu Area, due to occurrence of Miogypsinoides bantamensis, Miogypsinoides dehaartii, Miogypsina primitiva, and/or Miogypsina borneensis, respectively. Moreover these fauna are correlated with the fauna of the Assemblage 1 in the Küçükkoy Formation in Korkuteri Area (Figure 9).

\section{Conclusion}

The Miogypsinid foraminifera (Order Foraminiferida) in the Tethys Region are known to occur from the Early Oligocene (Rupelian) to Middle Miocene (Serravallian) age. Characteristic faunal assemblages from the Miogypsinid foraminiferal Biostratigraphy in Japan, Taiwan and Turkey have been known and correlated each other, respectively (Figures 6-7, 9). Judging from the correlation and analysis of faunal assemblages, the following evolution is established: Paleomiogypsina boninensis was proved to be a diagnostic species for the basal assemblage of the Early Oligocene (Rupelian), and Paleomiogypsina boninensis evolved from Pararotalia mecatepecensis due to having co-existence, and trochoid nepionic spirals in the Minamizaki Limestone, Ogasawara Islands, Japan (Matsumaru, 1996) (Figures 6-7). Miogypsinella boninensis evolved from Paleomiogypsina boninensis, and evolved into Miogypsinella ubaghsi during Late Oligocene (Chattian), based on the biostratigraphic relationship between the Minamizaki Limestone and limestones of Komahashi-Daini Seamount, Kyushu - Palau Ridge, Japan (Figures 6-7). Miogypsinella ubaghsi may evolve into Miogypsinella complanata due to nepionic acceleration, but there is no discovery on direct evidences in the field. However there is evidence of the evolution from Miogypsinella ubaghsi to Miogypsinella borodinensis (= Miogypsinoides formosensis) during the Late Oligocene (Chattian), based on the biostratigraphic relationship between limestones of Komahashi-Daini Seamount and basal Zone 5 drill cores of the Kita-Daitojima Limestone, Kita-Daito-Jima, Okinawa Prefecture, Japan (Figures 6-7). However Miogypsinella complanata is missing in both limestones as stated above, but probably has been existed as co-existence. Miogypsinella complanata and Miogypsinoides formosensis are found together, but both species are associated with Paleomiogypsina boninensis and Miogypsinoides bantamensis in Sample 97-486 in Section 4 and Sample 97-502 in Section 6 in the Küçükkoy Formation, Bey Dağlari Autochton, Menderes-Taurus Platform, Turkey (Matsumaru et al., 2010). Then Paleomiogypsina boninensis and Miogypsinella complanata are regarded as the reworking. During Late Oligocene (Chattian), Miogypsinoides formosensis evolved into Miogypsinoides dehaartii through Miogypsinoides bantamensis due to the nepionic acceleration, and Miogypsinoides dehaartii evolved into Miogypsina primitiva due to having the lateral chambers during the depositional age of the Küçükkoy Formation (Figures 6-7, 9). Moreover, Miogypsina primitiva evolved into Miogypsina borneensis due to the nepionic acceleration in the Küçükkoy Formation during Late Oligocene (Chattian) (Figures 6-7, 9). In the Early Miocene (Aquitanian), Miogypsina borneensis from the Küçükkyoy Formation evolved into Miogypsina globulina from the Karabayir Formation, Bey Dağlari Autochton (Figures 6-7, 9). Further Miogypsina globulina evolved into Miogypsina intermedia due to occurrence and nepionic 
acceleration (Drooger, 1952, 1963). Miogypsina intermedia evolved into Miogypsina cushmani due to the nepionic acceleration during Early Miocene (Burdigalian)/ Middle Miocene (Langhian) age, and these are shown in Indian and Japanese Miogypsina (Raju, 1974; Matsumaru, 1967, 1977; Matsumaru and Takahashi, 2004). Also their evolution is shown in the biostratigraphical correlation between the Karakuştepe Formation carrying Miogypsina globulina in Korkuteri Area, Bey Dağlari Autochton, Menders - Taurus Platform, and Sample E471 beds carrying Miogypsina intermedia in Ahirdaği Section in Maraş Area, Menderes - Taurus Platform, Turkey (Figure 9). Miogypsina nipponica (= M. antillea and M. cushmani steps of nepionic acceleration) was found from the Kamiyokoze Formation of the Middle Miocene (Serravallian) age, and this species evolved from Miogypsinid cushmani of nepionic acceleration by Indian and Japanese Miogupsinid researches (Raju, 1974; Matsumaru, 1980; Matsumaru and Takahashi, 2004). The ancestor of Miolepidocyclina burdigalensis (Gümbel), Lepidosemicyclina thecidaeformis (Rutten), Tania inokoshiensis Matsumaru, Boninella boninensis Matsumaru and Spinosemiogypsina antalyaensis Matsumaru, Özer and Sari isn't known, although some are considered, and it will be solved from further Miogypsinid foraminiferal Biostratigraphy. Some new genera by the author's research have been known from Miogypsinid foraminifera from the Philippines Archipelago, eastern Tethys region, and they will contact the unknown lineage soon.

\section{Acknowledgments}

The author thanks the Japan Society for the Promotion of Science (JSPS) for his fellowship researcher in 1992; and the General Directorate of Mineral Research and Exploration (MTA), Ankara, Turkey and their colleagues (Drs. and Messrs. E. Yazgan, E. Sirel, S. Acar, G. Tunay, S. Örcen, and K. Erdoğan) for their kind facility and comment. The author thanks Mr. M. Matsuo, Emeritus Professor of Saitama University, for his kind facility, and Mr. V. Grebro, and Ms. D. Duric, InTech, for their kind managing.

\section{References}

Berggren, W. A., Kent, D. V., Swisher III, C. C., and Aubry, M. P., 1995: A revised Cenozoic Geochronology and Chronostratigraphy. In, Berggren, W. A., Kent, D. V., Aubry, M. P. and Hardenbol, J. eds., Geochronology, Time Scale and Global Stratigraphic Correlation. SEPM Special Publication, Tulsa, 54: 129-212.

Blainville, H. M. Ducrotay de, 1827: Manuel de malacologie et de conchyliologie (1825). Paris: F. G. Levrault.

Blow, W. H., 1969: Late Middle Eocene to Recent planktonic foraminiferal biostratigraphy. In, Brönnimann, P. and Renz, H. H., eds, Proceedings of the First International Conference on Planktonic Microfossils. 1. Geneva: E. Brill, 199-422.

Cole, W. S., 1954: Larger foraminifera and smaller diagnostic foraminifera from Bikini Drill Holes. U. S. Geological Survey Professional Paper 260-0: 569-608.

1957: Larger foraminifera from Eniwetok Atoll. U. S. Geological Survey Professional Paper 260-V: 743-784.

Cushman, J. A., 1918: The larger fossil Foraminifera of the Panama Canal Zone. Bulletin of the U. S. National Museum, 103: 89-102.

Drooger, C. W., 1952: Study of American Miogypsinidae. Utrecht University, Thesis, 80 pp.

1963: Evolutionary trends in the Miogypsinidae. In, Von Koenigswald, G.H. R., Emeis, J. D., Buning, W. L. and Wagner, C. W. eds., Evolutionary Trends in Foraminifera. Elsevier, Amsterdam, 315-349. 
1993: Radial Foraminifera, Morphometrics and Evolution. Verhandelingen der Koninklijke Nederlandse Akademie van Wetenschappen, Afd. Natuurkunde, Eerste Reeks 41:242 pp.

Ehrenberg, C. G., 1839: Uber die Bildung dr Kreidefelsen und des Kreidemergels durch unsichtbare Organismen. Physikalische Abhandlungen der Koniglichen Akademie der Wissenschaften zu Berlin, 1838: 59-147.

Frost, S. H., and Langenheim, R. L., 1974: Tertiary larger foraminifera and scleractinian corals from Mexico. In, Cenozoic reef biofacies. 388 pp. Northern Ilinois University press, Dekalb.

Hanzawa, S., 1940: Micropaleontological studies of drill cores from a deep well in KitaDaito-Zima (North Borodino Island). Jubilee Publication of Professor H. Yabe's 60 th birthday, 755-802.

1957: Cenozoic foraminifera of Micronesia. Geological Society of America, Memoir, 66: $163 \mathrm{pp}$.

1964: The phylomorphogeneses of the Tertiary foraminiferal families, Lepidocyclinidae and Miogypsinidae. Science Reports of the Tohoku University, second ser. (Geology), 35: 295-313.

Kaneoka, I., Issiki, N., and Zashu, S., 1970: K-Ar ages of the Izu-Bonin Islands. Geochemical Journal, 4: 53-60.

Le Calvez, Y., 1949: Révision des foraminifères Lutetiens du Bassin de Paris. II. Rotaliidae et familles affines. Mémoires du Service de la Carte Géologique Détaillée de la France, 1-54.

Leupold, W., and Vlerk. I. M. van der, 1931: The Tertiary. Leidsche Geolofische Mededeelingen, Leiden, 5: 611-648.

Matsumaru, K., 1967: Geology of the Tomioka area, Gunma Prefecture with a note on "Lepidocyclina" from the Abuta Limestone Member. Science Reports of the Tohoku University, second ser. (Geology), 39: 113-147.

1968: Miogypsinid population from the Tungliang Well TL-1 of the Penghu Islands, China. Transactions and Proceedings of the Paleontological Society of Japan, New Ser. 72: 340-344.

1971: Studies on the genus Nephrolepidina in Japan. Science Reports of the Tohoku University, second ser. (Geology), 42: 97-185.

1972: The genus Miolepidocyclina from Japan. In, Prof. Jun-Ichi Iwai Memorial Volume, 679-681. Sasaki Pub. Co., Sendai.

1977: Neogene stratigraphy of the northern to northeastern marginal areas of the Kanto Mountainland, Central Japan. Journal of the Geological Society of Japan, 83: 213225. (in Japanese with English abstract)

1980: Note on a new species of Miogypsina from Japan. In, Professor Saburo Kanno Memorial Volume, 213-219. Sasaki Pub. Co., Sendai.

1982. On Miogypsina (Miogypsina) kotoi Hanzawa from Zone N. 16 on Dogo Island, Oki Islands,Japan. Proceedings of the Japan Academy, 58, ser. B: 52-55.

1990: A new genus of the Miogypsinid foraminifera from Southwest Japan. Transactions and Proceedings of the Paleontological Society of Japan, New Ser. 158: 535-539. 1996: Tertiary larger foraminifera (Foraminiferida) from the Ogasawara Islands, Japan. Paleontological Society of Japan, Special Papers, 36: 239 pp.

Myint Thein, and Ogawa, Y., 1993: Early Miocene (Aquitanian) larger foraminifera from the Shimizu Formation, Ashizuri Cape, Kochi Prefecture, Shikoku, Japan. Transactions and Proceedings of the Paleontological Society of Japan, New Ser. 169: 1-14. 
and Takahashi, M., 2004: Studies on the genus Miogypsina (Foraminiferida) in Japan. Journal of Saitama University, Faculty of Education (Mathmatics and Natural Sciences), 53: 17-39.

Sari, B., and Özer, S., 2010: Larger foraminiferal biostratigraphy of the middle Tertiary of Bey Dağlari Autochton, Menderes-Taurus Platform, Turkey. Micropaleontology, 56: 439-463.

Mishra, P. K., 1996: Study of Miogypsinidae and associated planktonics from Cauvery, Krishna-Godavari and Andaman Basins of India. Geoscience Journal, 17: 123-251.

Mohiuddin, M. M., Ogawa, Y., and Matsumaru, K., 2000: Late Oligocene larger foraminifera from the Komahashi-Daini Seamount, Kyushu-Palau Ridge and their tectonic significance. Paleontological Research, 4: 191-204.

Nomura, M., and Ohira, Y., 1998: Fission track age of the Miocene tuff in the Tomioka area, Gunma Prefecture. Journal of Gunma Museum of Natural History, 2: 35-42. (in Japanese) and 2002: Fission track age of the Miocene Haratajino and Shiohatado tuffs in the Tomioka Group, Gunma Prefecture, Central Japan. Journal of Gunma Museum of Natural History, 6: 75-80. (in Japanese)

Ishikawa, H., Kaneko, M., and Matsumaru, K., 2003; The discovery of Miogypsina from the Miocene Series of Kanayama Hill, Ota City, Gunma Prefecture, Central Japan. Journal of the Geological Society of Japan, 109: 611-614. (in Japanese)

Ohde, S., and Elderfield, H., 1992: Strontium isotope stratigraphy of Kita-Daito-Jima Atoll, North Philippine Sea: implications for Neogene sea-level change and tectonic history. Earth and Planetary Science Letters, 113: 473-486.

Raju, D. S. N., 1974: Study of Indian Miogypsinidae. Utrecht Micropaleontological Bulletins, 9: 148 pp.

Rutten, L. M. R., 1911: Over Orbitoiden uit de omgeving or Balik Papan-baai (Oostkust van Borneo). Verhandlingen van het Geologisch Mijnbouwkundig Genootschap voor Nederlandsch Kolonien, Amsterdam, 25 Febr., 1911. 1/1122-17/1139.

Sacco, F., 1893: Sur quelques Tinoporinae du Miocène de Turin. Bulletin de la Sociéte Belge de Géologie, de Paléontologie, et d'Hydrologie (1893-1894) 7: 204-207.

Tan Sin Hok, 1932: Over Cycloclypeus voorloopige resultaten einer biostratigrafische studies. Mijngenieur Bandoeng, 11: 233-242.

1936: Zur Kenntniss der Miogypsiniden. Ingenieur in nederlandsch-Indie, IV, Mijnbouw en Geologie, 3 (3): 45-61; 3 (5); 84-98; 3 (7): 109-123.

1937: Weitere Untersuchungen uber die Miogypsiniden I,und II. Ingenieur in nederlandsch-Indie, Mijnbouw en Geologie, 4 (3): 35-45; 4 (6): 87-113.

Tsunakawa, H., 1983: K-Ar dating on volcanic rocks in the Bonin Islands and its tectonic implication. Tectonophysics, 95: 221-232.

Ujiie, H., 1973: Distribution of the Japanese Miogypsina, with description of a new species. Restudy of the Japanese Miogypsinids, Part 3. Bulletin of the National Science Museum, Tokyo, 16: 99-114.

Uysal, S., Sirel, E., and Gündüz, H., 1985: Guneydogu anadolu boyunca (Muş-Palu-MaraşHatay) bazi Tersiyer Kesitleri. Maden Tetkik Ve Arama Genel Müdürlüğ̈̈u (Jeoloji Etudleri Dairesi) Jeol. Elid. Ar., No. 236 (in Turkish)

Vaughan, T. W., 1928: Subfamily Miogypsininae Vaughan. In, Cushman, J. A., 1928, Foraminifera their classification and Economic Use, Special Publications Cushman Laboratory for Foraminiferal Research, 1: $401 \mathrm{pp}$.

Yabe, H., and Hanzawa, S., 1928: Tertiary foraminiferous of Taiwan. Proceedings of Imperial Academy of Tokyo, 4: 222-225. 


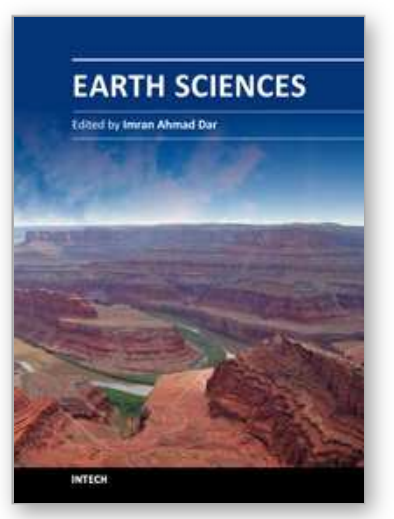

\author{
Earth Sciences \\ Edited by Dr. Imran Ahmad Dar
}

ISBN 978-953-307-861-8

Hard cover, 648 pages

Publisher InTech

Published online 03, February, 2012

Published in print edition February, 2012

The studies of Earth's history and of the physical and chemical properties of the substances that make up our planet, are of great significance to our understanding both of its past and its future. The geological and other environmental processes on Earth and the composition of the planet are of vital importance in locating and harnessing its resources. This book is primarily written for research scholars, geologists, civil engineers, mining engineers, and environmentalists. Hopefully the text will be used by students, and it will continue to be of value to them throughout their subsequent professional and research careers. This does not mean to infer that the book was written solely or mainly with the student in mind. Indeed from the point of view of the researcher in Earth and Environmental Science it could be argued that this text contains more detail than he will require in his initial studies or research.

\title{
How to reference
}

In order to correctly reference this scholarly work, feel free to copy and paste the following:

Kuniteru Matsumaru (2012). Miogypsinid Foraminiferal Biostratigraphy from the Oligocene to Miocene Sedimentary Rocks in the Tethys Region, Earth Sciences, Dr. Imran Ahmad Dar (Ed.), ISBN: 978-953-307861-8, InTech, Available from: http://www.intechopen.com/books/earth-sciences/miogypsinid-foraminiferalbiostratigraphy-from-the-oligocene-to-miocene-sedimentary-rocks-in-the-tet

\section{INTECH}

open science | open minds

\author{
InTech Europe \\ University Campus STeP Ri \\ Slavka Krautzeka 83/A \\ 51000 Rijeka, Croatia \\ Phone: +385 (51) 770447 \\ Fax: +385 (51) 686166 \\ www.intechopen.com
}

\author{
InTech China \\ Unit 405, Office Block, Hotel Equatorial Shanghai \\ No.65, Yan An Road (West), Shanghai, 200040, China \\ 中国上海市延安西路65号上海国际贵都大饭店办公楼405单元 \\ Phone: +86-21-62489820 \\ Fax: $+86-21-62489821$
}


(C) 2012 The Author(s). Licensee IntechOpen. This is an open access article distributed under the terms of the Creative Commons Attribution 3.0 License, which permits unrestricted use, distribution, and reproduction in any medium, provided the original work is properly cited. 